2

3

4

5

6

7

8

9

\title{
ENSO and the recent warming of the Indian Ocean
}

\author{
Abish B ${ }^{1, *}$, Annalisa Cherchi ${ }^{2}$, Satyaban B. Ratna ${ }^{3,4}$ \\ ${ }^{1}$ Nansen Environmental Research Centre India, Kochi, India \\ ${ }^{2}$ Fondazione Centro Euro-Mediterraneo sui Cambiamenti Climatici, and Istituto Nazionale di \\ Geofisica e Vulcanologia, Bologna, Italy \\ ${ }^{3}$ Application Laboratory, Japan Agency for Marine-Earth Science and Technology, Yokohama, \\ Japan \\ ${ }^{4}$ Climatic Research Unit, School of Environmental Sciences, University \\ of East Anglia, Norwich, UK
}

\section{*Corresponding Author}

Abish B

Nansen Environmental Research Centre India,

$$
\text { Kochi-682016, India }
$$

Email: abishb@gmail.com 


\section{Abstract}

The recent Indian Ocean (IO) warming and its relation with the El Niño Southern Oscillation (ENSO) is investigated using available ocean and atmospheric reanalyses. By comparing the events before and after 1976 (identified as a threshold separating earlier and recent decades with respect to global warming trends), our results indicate that the Indian Ocean had experienced a distinct change in the warming pattern. After 1976, during the boreal summer season the cold anomalies in the IO were replaced by warm anomalies in both warm (El Niño) and cold (La Niña) ENSO events. Strong sinking by upper level winds and the associated anomalous equatorial easterly winds created favorable conditions for the IO warming from $90^{\circ} \mathrm{E}$ towards the western IO. The zonal temperature gradient thus created, strengthened the equatorial easterly wind anomalies that further intensified the warming. Our study highlights that after 1976, atmospheric and oceanic fields changed mostly during La Niña, with both

Key words: SST, Indian Ocean warming, ENSO, Walker circulation, Climate variability 


\section{Introduction}

The warming of the Indian Ocean (IO) in the recent decades has evinced interest among the research community due to its important role in driving the global climate variability (Levitus et al., 2005; Barnett et al., 2005; Alory et al., 2007; Rao et al., 2012, Ratna et al., 2016 among others). Observations indicate that among the world's oceans, the IO has warmed more rapidly in recent times (Levitus et al., 2000; Du et al., 2009, Han et al., 2014) causing a significant shift in the heat budget of the climate system (Alory and Meyers 2009).

One of the climate indices that influences the IO warming is ENSO (Schott et al. 2009), which through atmospheric teleconnection modulates the thermodynamic fluxes at the sea surface (Klein et al., 1999; Alexander et al., 2002). Observations and simulations concur that the transport of surplus heat from the Pacific Ocean to the IO has accounted for the recent warming of IO (Dong et al., 2016). It is argued that the displacement of the convergence zones due to El Niño strengthened the sinking of atmospheric circulation cells, thereby reducing the cloud cover and the increased absorption of solar radiation contributing to the warming of IO (Klein et al., 1999; Mayer et al., 2013). Through the changes in the atmospheric circulation in response to the warm and cold ENSO phases, the heat content is redistributed across the tropical oceans (Mayer et al., 2014) causing a large part of the warming to occur in the upper $700 \mathrm{~m}$ (Levitus et al., 2005).

The enormous increase of greenhouse gas concentration in the atmosphere has also intensified the IO warming (Tyrrell, 2011; Du and Xie, 2008; Dong et al., 2014). Among the greenhouse gases (GHG), $\mathrm{CO}_{2}$ has accounted for the $90 \%$ of the increased radiative forcing (Hansen and 
ocean surface (Bindoff et al., 2007;Trenberth et al., 2009; Balmaseda et al., 2013a) resulting in its warming (Levitus et al., 2005). At the same time, the atmospheric aerosols offset the warming due to GHGs and induce a basin wide cooling (Roeckner et al., 1999; Dong and Zhou, 2014). The incessant global warming and its impact on the dominant mode of tropical climate variability, i.e. ENSO, are a source of uncertainty as the anthropogenic changes are interspersed with the natural climate variability (Fedorov and Philander, 2000; Williams and Funk, 2011). Therefore, changes in the atmospheric circulation (Alexander et al. 2002; Lau and Nath, 2003; Tanaka et al., 2004; Vecchi et al., 2006) and the associated ocean processes (Chambers et al., 1999) during ENSO assume importance in the context of the basin wide warming of the IO.

After the late 70s, El Niño events were ensued by a distinct shift in the onset of the warming in the Pacific Ocean (Wang, 1995). Trenberth et al (2007) while examining the global surface temperature trends from 1860 to 2000 found that the period 1946-1975 had a relatively stable global mean temperature while 1976- 2000 had rising temperatures which resulted in a net warming of about 0.2 to 0.3 degrees. The steep transition in the temperature is also evident in a composite time series of 40 environmental variables as illustrated by Ebbesmeyer et al. (1991). In fact, post-1976 ENSO activity tends more toward warm phases and it has been linked to the decadal changes in the climate throughout the Pacific basin (Wang et al., 1995; Trenberth et al., 2002). According to the literature, pre-1976 ENSO events began along the west coast of South America and developed westward, while after 1977 the warming developed from the west, so that the evolution of ENSO events changed abruptly around 1976/1977. Vertical temperature gradients and upwelling in the eastern tropical Pacific play a key role in westward development, while eastward development relies more on east-west temperature gradients and advection in the central tropical Pacific (Trenberth et al.2002). The recent SST warming trends in the western equatorial Pacific appeared to be the result of the greater frequency and amplitude of so-called central Pacific (CP) El Nino events (Lee and Mac Phaden, 2010; Yeh et al 2011). Accompanied 
by these changes in the surface winds and ocean surface processes in the Pacific, the IO experienced a sudden surface warming around 1976-77 suggesting an abrupt change in the region (Terray, 1994). The consequence is evident in La Niña events after 1976 when the tropical IO showed a strong warming instead of basin wide cooling (Chowdary et al., 2006). As a result, the equatorial westerly winds weakened thereby further accelerating the warming of the surface waters of the IO (Alory and Meyers 2009).

Fig. 1a shows the time series of global surface temperature (NOAA) and of SST anomalies in the IO region $\left(40^{\circ} \mathrm{E}-110^{\circ} \mathrm{E} ; 10^{\circ} \mathrm{S}-25^{\circ} \mathrm{N}\right)$. The green bars and the red line indicate the trend in global surface temperature and in the IO SST respectively. A sudden spike in global temperature and a monotonous increase in IO SST are seen around 1976 and therefore a threshold between two periods with different characteristics can be taken in 1976. Accordingly, we consider composite pre and post 1976 as the distinction between "earlier" and "recent" period to investigate the El Niño and La Niña events conducive for the IO warming during the boreal summer (JJAS). Though the ENSO peaks during winter, the IO warming is larger in summer (Ratna et al. 2016) and its teleconnection with the summer monsoon is known to be strong in this season (Cherchi and Navarra, 2013). High IO SST weakens the horizontal thermal gradient that drives the Indian summer monsoon circulation (Abish et al., 2013); therefore, any change in the IO warming pattern during boreal summer is significant from a meteorological point of view. Studies have shown a lag in the IO warming after the mature phase of El Niño (eg. Chambers et al. 1999). However, recently Roxy et al (2014) demonstrated the simultaneous warming effect of El Niño on IO SST in summer. Chowdary et al. (2006) also showed a similar warming effect over the tropical Indian Ocean during the La Niña in JJAS. Following from these findings, our analysis focuses on the association between IO warming and ENSO during summer. 
The study is organized as follows: Section 2 lists and describes the datasets, and the atmospheric and oceanic reanalyses used. Section 3 collects the main results organized into: (i) relationship between remote SST patterns and Indian Ocean warming (Section 3.1); (ii) description of the differences in the Indian Ocean characteristics between pre and post 1976 ENSO events (Section 3.2). Finally, Section 4 includes the main conclusions of the study and associated discussion.

\section{Description of datasets, atmospheric and oceanic reanalyses}

Monthly mean SST for the years 1950 to 2010 is taken from the Hadley Centre Global Sea Ice and Sea Surface Temperature (HadISST) (Rayner et al., 2003). El Niño and La Niña years used to compute the composites are identified from the Oceanic Niño Index (ONI), which is NOAA's primary indicator to monitor the El Niño and La Niña. This index, which is the running mean of 3-month SST anomalies in the Niño 3.4 region $\left(5^{\circ} \mathrm{N}-5^{\circ} \mathrm{S}, 120^{\circ} \mathrm{W}-170^{\circ} \mathrm{W}\right)$ based on 30 year base periods (Smith et al., 2008) is used in this study. The El Niño and La Niña events determined based on the ONI threshold of $\pm 0.5^{\circ} \mathrm{C}$ (Trenberth, 1997) in summer are listed in Table 1.

Monthly mean wind $\left(\mathrm{ms}^{-1}\right)$ and omega $(\mathrm{Pa} / \mathrm{s})$ are taken from the NCEP/NCAR reanalysis (Kalnay et al., 1996). Numerous studies on ocean warming (Alexander et al. 2002; Trenberth et al. 2002; Alory et al., 2007; Chowdary et al., 2006; Chakravorty et al., 2014) have used NCEP/NCAR data extensively to analyze the role of anomalies in the atmospheric parameters associated with the ocean warming. Recently, Ratna et al (2016) compared three different atmospheric reanalyses (NCEP, ERA40 and JRA55) to study the climate variability associated with the IO warming and found similar characteristics among the datasets. Here as well we have compared the results using the NCEP/NCAR reanalysis with those using ERA-20C (Poli et al., 2013), 20CRv2 (Compo et al., 2011) and JRA55 (Kobayashi et al., 2015) reanalyses. 
The results obtained are adequately similar (see the discussion in sections below as well as additional figures in the supplementary material).

Oceanic fields (thermocline depth, temperature and zonal current) for the period 1958 to 2010 are taken from the CMCC-INGV Global Ocean Data Assimilation System (CIGODAS; Masina et al., 2011). CIGODAS consists of the Ocean General Circulation Model (OGCM) OPA 8.2 (Madec et al.,1999) in the ORCA2 global configuration (horizontal resolution of $2^{\circ}$ longitude $\times 2^{\circ}$ latitude) and an optimal interpolation (OI) scheme based on the System for Ocean Forecasting and Analysis (SOFA) assimilation software (De Mey and Benkiran, 2002) implemented to the global ocean (Bellucci et al., 2007). The atmospheric fluxes used as external forcing for the oceanic reanalysis are taken from the European Center for Medium range Weather Forecasts (ECMWF) data fields. Similar to the atmospheric analysis, comparison of CIGODAS was done with another ocean reanalysis product, ORAS4 (Balmaseda et al., 2013b) and the results are presented in the supplementary material.

Both atmospheric and oceanic variables are detrended before computing the anomalies to remove the long-term trends and the reference climatology is computed for the whole period 1950-2010. In the case of CIGODAS, ORAS4 (i.e. global ocean reanalyses) and JRA55, the data are available starting from 1958, so the events before that year are not included and therefore, 5 events out of 8 for El Niño and 6 events out of 10 for La Niña are used in the analysis (Table 1). The whole analysis is based on the boreal summer (i.e. JJAS) mean.

\section{Results}

\subsection{Indian Ocean warming (IOW) and its relationship with remote SST patterns}

To establish the relationship between ENSO and IO SST, the correlation with the detrended SST averaged over $10^{\circ} \mathrm{S}$ to $25^{\circ} \mathrm{N} ; 40^{\circ} \mathrm{E}$ to $110^{\circ} \mathrm{E}$ in the Indian Ocean and Niño 3.4 during 
JJAS is computed for the period 1950-2010. The statistical analysis shows a high correlation of 0.65 , significant at the $95 \%$ level as measured using Student's $t$-test, suggesting the important role of ENSO in the IO warming. However, if the correlation between ENSO index and SST averaged in the IO is computed for the years after 1976, the values drop to 0.52. Looking at spatial patterns of the correlation between IO SST and Nino 3.4 index, the main difference is that the area with high and significant values is larger before 1976 (Fig. 1b). But, after 1976 the ENSO influence is confined to west of $90^{\circ} \mathrm{E}$ and south of $18^{\circ} \mathrm{N}$ (Fig. 1c) and the possible cause will be explained in the following section. Roxy et al (2014) have also shown a significant positive correlation between the summer mean SST in eastern Pacific and western IO.

\subsection{Analysis of the differences pre/post 1976 in the connection between ENSO and the Indian Ocean}

Figure $2(a, b, c, d)$ shows the JJAS composites of SST anomalies for El Niño and La Niña events before and after 1976. The climatology for the entire period (1950-2010) is used to compute the anomalies, but as described in Section 2 the fields are detrended before the computation of the anomalies. Eight El Niño and ten La Niña events have been used to compute the composite of the anomalies for the period 1950-1975, while nine El Niño and five La Niña events have been considered for the period 1976-2010 (see Table 1).

Over the Pacific Ocean, the SST pattern is almost symmetric comparing El Niño and La Niña events in the pre and post 1976 composites. On the contrary, in the Indian Ocean during El Niño events pre-1976 the SST anomalies are cold all over the Indian Ocean, except for the Arabian Sea where they are warm (Fig. 2a). Conversely, during La Niña events in the same period the anomalies are mostly cold over the Indian Ocean except in the south-eastern part near Sumatra (Fig. 2c). These opposite patterns with positive anomalies in the western Indian Ocean and negative ones in the south-eastern equatorial sector recall the typical Indian Ocean 
Dipole pattern (Saji et al., 1999) in its positive phase and vice-versa. After 1976 the anomalies in the Indian Ocean in response to the ENSO events differ completely from those in the earlier period (Fig. 2b, d). In fact, in the El Niño composite IO SST are positive everywhere (mostly exceeding $0.2^{\circ} \mathrm{C}$ ), except in the region close to the Indonesian archipelago. Interestingly, similar to El Niño conditions, warm anomalies of $0.2{ }^{\circ} \mathrm{C}$ are also seen in La Niña composite over large areas of the IO that extends to the western Pacific warm pool (Fig. 2d), indicating the replacement of cool surface waters by warm waters during La Niña.

Table 1 shows that the La Niña's of 1988, 1998 and 2010 were preceded by El Niño events. It is suggested that the warm SST anomalies over the Indian Ocean during El Niño years may prevail longer than usual due to local ocean-atmospheric interaction and may persists into the following La Niña events (Roxy et al. 2014). Among them, the 2010 La Niña was very unusual as its rapid transition from the El Niño in the Pacific was accompanied by a prominent warming during spring and early summer in the tropical IO. This suggests the persistence of warm SST anomalies in the IO despite the quick transition from El Niño to La Niña (Priya et al. 2015). Fig 2e, depicts the detrended timeseries of Niño 3.4 SST (broken line) and IO SST (solid line) anomalies for the period 1950-2010. From the figure it is likely that the persistence of warm anomalies from the preceding strong El Nino events may have contributed to the most of the post-1976 composite warming seen during La Niña.

From the atmospheric point of view, the composite wind anomaly at $850 \mathrm{hPa}$ shows the weakening of the prevailing winds in the IO west of $90^{\circ}$ E during pre-1976 El Niño (Fig. 3a) and strong westerlies throughout the equatorial Indian Ocean during La Niña (Fig. 3c). However, in post-1976 events anomalous easterlies/south easterlies dominate the IO west of $90^{\circ} \mathrm{E}$ (Fig. 3b \&3d), when compared with the climatological (Fig 3e). Anomalous easterlies during the post-1976 period over the Indian Ocean create favorable conditions for the warming of the basin. The westward advection of warm surface waters from the west Pacific warm pool 
towards the IO induces positive sea level pressure anomalies that enhances the surface easterly anomalies (Dong et al. 2016). The anomalous equatorial easterlies thus created during both events have effectively excited the positive SST anomalies further assisting the warming of the IO west of $90^{\circ} \mathrm{E}$. The same composite but computed using winds from JRA-55, ERA 20C and 20CRv2 reanalyses give similar results (Supplementary figure Fig S1).

Observation and modeling studies (Pan and Oort, 1983; Yamagata et al., 2004; Tokinaga et al., 2012) have illustrated the close linkage between SST and the Walker circulation. The vertical section of the detrended zonal wind $\left(\mathrm{ms}^{-1}\right)$ and omega $\left(\mathrm{Pa} \mathrm{s}^{-1}\right)$ averaged between $5^{\circ} \mathrm{S}-10^{\circ} \mathrm{N}$ indicates that during El Niño events prior to 1976 the circulation is characterized by strong subsidence (denoted by positive anomalies) over the eastern IO and ascending motion elsewhere with higher intensities over the central and western Indian Ocean (Fig 4a). On the other hand, during La Niña events prior to 1976 ascending winds dominates the eastern IO (Fig 4c). However, after 1976 the El Niño events exhibit strong sinking motion in the eastern IO with decreasing intensity towards west (Figs. 4b). Similar strong sinking motion in the eastern IO is also seen in La Niña events after 1976 (Figs. 4d) but with strong ascending winds around $60^{\circ} \mathrm{E}-$ $70^{\circ} \mathrm{E}$. Comparing the post- 1976 vertical circulation of both events, there is a change in the direction/intensity in the central and western IO, but the highest subsidence is clearly located in the eastern IO. The sinking (rising) wind motion and associated high-pressure (low-pressure) conditions explains the observed equatorial easterly anomalies seen in Figs. 3b and 3d.

The same analysis using JRA-55, ERA-20C and 20CRv2 reanalyses is shown in Fig S2. A comparison of the results from the different reanalyses indicates that most of the similarities are found in the lower levels, while they differ in the upper troposphere, showing a different picture of the changes occurring to the Walker circulation. Considering the nature of the reanalysis products, the in 20CRv2 and ERA-20C are more similar as they assimilate only the surface pressure (Poli et al., 2013). 
It is seen that the changes in the circulation and the winds are more prominent in the equatorial Indian Ocean (EEIO) between pre-1976 and post-1976 period (Figs 3 and 4). This explains the possible cause for the absence of significant correlation between IO-SST and Niño 3.4 during post-76. It could be argued that the warming in the EEIO could be more related to the natural variability of the Indian Ocean, rather to the influence from the Pacific Ocean. Considering all the El Niño's post-1976, the events that most contributes to the warming in the EEIO are 1987, 1991, 1992, 2002, 2004 and 2009 (not shown). They do not share specific characteristics, neither in terms of El Nino-type, nor in terms of intensity or in terms of SST pattern in the North Pacific.

The negative SST anomalies in the northwest Pacific in the composite post-76 are associated with the cold phase of the Pacific decadal oscillation (PDO) of the period. The PDO itself is known to have an impact on the SST of the Indian Ocean, with the negative (positive) phase associated with warm (cold) basin SST anomalies (Krishnamurty and Krishnamurty 2014). In their work the role of El Niño/La Niña and of the two phases of the PDO has been separated in terms of the effects on the Indian summer monsoon rainfall. In our analysis the effect of the PDO is not systematically distinguished from that of ENSO, but the comparison of the composite pre and post1976 highlight the role of the warm phase of the PDO and how it also contributes to the warming of the IO basin.

Even after removing the strong El Niño events from the composite i.e. (1982 and 1997), the overall SST pattern is not much different when compared with Fig 2b. Some differences can be noted in the IO where it seems that without the two extreme El Niño's the warm anomalies are bit more intense, mostly toward the eastern side of the basin. In fact, looking at each single El Nino events post-1976 in both 1982 and 1997 the SST in the eastern Indian Ocean are negative (i.e. 1997 has clear positive IOD pattern, while 1982 have positive anomalies on the west and negative on the east (not shown). 
During the El Niño events before 1976 the thermocline (i.e. the depth of strongest vertical temperature gradient) is deeper south of the equator and in the northern Arabian Sea but shoals around the Equator in both the eastern and western basin (Fig. 5a). The pattern is almost opposite during La Niña events before 1976, with the largest deepening in the eastern IO north of the Equator (Fig. 5c). Looking at the events after 1976 the patterns largely differ. In fact, for the El Niño events the warming of the IO coincides with the deepening of the thermocline, mostly along the Equator (Fig. 5b), while during La Niña, the deepening takes place in the eastern Indian Ocean with the thermocline mostly shoaling in the west (Fig 5d). Figures 5e and $5 \mathrm{f}$ represent the differences in thermocline depth between the post76 and pre76 periods of El Niño and La Niña events respectively. The westward advection of warm surface waters by means of anomalous easterlies deepens the thermocline thereby reducing the upwelling and in turn assists the enhancement of SST (Han et al., 2006; Han et al.,2014; Dong et al. 2016). Accordingly, when compared with the climatological (Fig 5g), it is evident that during both events the post-76 thermocline deepens over most of the IO creating favourable conditions for warming of surface waters by slowing down the mixed layer cooling by vertical processes. The patterns described are also confirmed in the ORAS4 oceanic reanalyses (Fig. S3). The results are synonymous with the ongoing IO warming pattern in the recent decades.

The surface cooling of the IO during the El Niño events before 1976 expands to the subsurface water, except for a delimited warming that maximizes at $55^{\circ} \mathrm{E}$ and $120 \mathrm{~m}$ depth (Fig. 6a). After 1976 the IO surface warming during the El Niño events expands also to the subsurface up to 90-100 m with cooling below that depth (Fig. 6b). Similar patterns are found using ORAS4 data (Fig. S4). During La Niña events it is quite the opposite. In fact, during the events pre1976 there is a vertical gradient with negative anomalies above $90 \mathrm{~m}$ and positive below (Fig. 6c). After 1976 the pattern is opposite but the subsurface cooling is only confined to $60-90^{\circ} \mathrm{E}$ 
(Fig. 6d). Also in this case the patterns are confirmed in the other oceanic reanalysis considered (Fig. S4).

The vertical gradients in the temperature anomalies are associated with similar gradients in the zonal currents. In fact, the vertical profile of the zonal currents averaged in the latitudes 0 to $20^{\circ} \mathrm{N}$ shows negative anomalies above about $100 \mathrm{~m}$ during El Niño and La Niña events before 1976 (Fig. 7a,d) and vice versa during post76 events. Similarly in agreement with the previous results, the difference plots (Fig 7e,f) shows positive anomalies west of $90^{\circ} \mathrm{E}$ during post-1976 when compared with the climatology (Fig 7g), indicating its association with the IO warming. Here the results are also confirmed for the ORAS4 oceanic reanalysis (Fig. S5). The analysis of the oceanic variables provides a picture of the conditions in the sub-surface of the IO in the different cases considered that was not reported in literature so far, according to our knowledge. An exhaustive understanding of the dynamics in the Indian Ocean is beyond the objective of the present study and would require specific sensitivity experiments with an ocean model that could be subject of a forthcoming study.

Fig. 8 summarizes the main characteristics of atmospheric fields during El Niño and La Niña years comparing pre and post 1976 events. In particular, before 1976 the local circulation over the Indian Ocean is such that in both El Niño and La Niña the equatorial wind anomalies are mostly westerlies (even if they are stronger during La Niña, they have a northerly component during El Niño). The result is an opposite SST pattern with general cooling in both cases but with positive anomalies in the Arabian Sea during El Niño and close to Sumatra during La Niña. The patterns are almost symmetric between the two phases of ENSO and in the IO recall the Indian Ocean Dipole mode in its positive and negative phase, respectively. On the contrary, after 1976 during both ENSO phases the SST anomalies are overall positive in the IO. Here, the local atmospheric circulation is not exactly symmetric and the surface winds are mostly 
anomalous easterlies along the Equator. The strong subsiding winds in the eastern IO enhance

327 the sea level pressure anomalies and the consequent increased zonal temperature gradient intensifies the surface easterly anomalies. The resultant warm water advection accompanies the warming of the sea surface mostly to the west of $90^{\circ} \mathrm{E}$.

\section{Conclusions}

The present study highlights the important role of ENSO in the recent warming of the IO. In fact, the changes that occurred in the atmospheric circulations and in the ocean in the late $70 \mathrm{~s}$ have resulted in the warming of the IO during the El Niño and La Niña events of boreal summer. Our analysis shows that after 1976, the weakening of surface equatorial westerlies have a role in the warming of otherwise cold waters of IO during La Niña. The weakening of wind is associated with a strong anomalous descending motion over the eastern IO compared to the western regions of IO. The regions of subsiding winds are associated with high-pressure regions and from these regions, surface anomalous easterlies move towards low-pressure areas (in this case western IO). The steep zonal temperature gradient thus created and the intensification of the anomalous easterlies in the equatorial IO may have assisted the transport of surplus heat from the Pacific Ocean into the IO. Therefore, the combined warming due to El Niño and La Niña is considered to have contributed to the recent persistent warming of IO with strong warming from $90^{\circ} \mathrm{E}$ to the western IO. Analysis of oceanic data confirms the penetration of warm waters into deeper levels during both the events and the accumulation of heat in the upper levels favor the warming towards the western IO post 1976 by slowing down the mixed layer cooling by vertical processes. Further analysis suggests the post-76 warming of La Niña may have a contribution from the preceding strong El Niño as evident from the prominent warming in 1988, 1998 and 2010. It is likely that these few La Niña events contributed the most to the post-1976 composite warming. Compared to the very large positive SST anomalies of the 

strong El Niño events, the La Niña that followed were less intense in IO to cool the SST, leading to the sustained warming of the IO during both events. However, even after removing the strong El Niño events of 1982 and 1997 from the post-76 composite, the IO shows warm anomalies almost covering the entire basin indicating that the changes in the composite post-76 are only partially driven by the two extreme events recorded.

\section{Acknowledgements}

This research work has received funding from the European Union Seventh Framework Programme (FP7/2012-2015) under the grant agreement $\mathrm{n}^{\circ}$ 295092, INDO-MARECLIM coordinated by Nansen Environmental Research Centre-India and from the Research Council of Norway, INDNOR/NORKLIMA INDIACLIM. Project No. 216554. The authors are thankful to Dr.Girishkumar M.S., INCOIS for the creative scientific discussions. We are grateful to the two anonymous reviewers for their valuable comments and suggestions.

\section{References}

Abish B, Joseph PV, Johannessen OM. 2013. Weakening trend of the tropical easterly jet stream of the boreal summer monsoon season 1950--2009. J. Climate 26 9408-9414, doi: 10.1175/JCLI-D-13-00440.1.

Alexander MA., BladeI, Newman M, Lanzante JR, Lau N.-C, Scott JD.2002. The atmospheric bridge: The influence of ENSO teleconnections on air-sea interaction over the global oceans. $J$. Clim 15: 2205-2231

Alory G, Meyers G. 2009. Warming of the Upper Equatorial Indian Ocean and Changes in the Heat Budget (1960-99). J. Climate 22: 93-113.

Alory G, Wijffels S, Meyers G. 2007. Observed temperature trends in the Indian Ocean over 1960-1999 and associated mechanisms. Geophys. Res. Lett 34:,L02606, doi:10.1029/2006GL028044.

An S-I, Wang B. 2000. Interdecadal changes of the structure of the ENSO mode and its impact on the ENSO frequency. J. Climate 13: 2044-2055.

Balmaseda MA, Trenberth KE, Källén E. 2013a. Distinctive climate signals in reanalysis of global ocean heat content.Geophys. Res. Lett 40:1754-1759, doi:10.1002/grl.50382.

Balmaseda MA, Mogensen K, Weaver AT. 2013b. Evaluation of the ECMWF ocean reanalysis system ORAS4. Q.J.R. Meteorol. Soc 139: 1132-1161. doi:10.1002/qj.2063 
Barnett TP, Pierce DW, Achutarao KM, Gleckler PJ, Santer BD, Gregory JM, Washington WM. 2005. Penetration of human-induced warming into the world's oceans. Science 309: 284-287

Bellucci A., Masina S., Di Pietro P., Navarra A. 2007. Using temperature-salinity relations in a global ocean implementation of a multivariate data assimilation scheme. Monthly Weather Review 135: 3785-3807.

Bindoff NL, et al. 2007. Observations: oceanic climate change and sea level. In: Climate Change 2007: The Physical Science Basis, pp. 385-432, Cambridge University Press, New York, ISBN 0521705967.

Chambers D, Tapley B, Stewart R. 1999. Anomalous warming in the Indian Ocean coincident with El Niño. J. Geophys.Res 104: 3035-3047

Chakravorty S, Chowdary JS, Gnanaseelan C. 2014. Epochal changes in the seasonal evolution of Tropical Indian Oceanwarming associated with El Niño. ClimDyn42:805-822

Cherchi A, Navarra A. 2013. Influence of ENSO and of the Indian Ocean Dipole on the Indian summer monsoon variability. Clim Dyn 41: 81-103 DOI 10.1007/s00382-012-1602-y

Chowdary J, Gnanaseelan SC, Vaid BH, Salvekar PS. 2006. Changing trends in the tropical Indian Ocean SST during La Niña years.Geophys. Res.Lett 33: L18610

Compo et al. 2011. The Twentieth Century Reanalysis Project. Quarterly J. Roy. Meteorol. Soc 137: 1-28. DOI: 10.1002/qj.776.

De Mey P, Benkiran M. 2002. A multivariate reduced-order optimal interpolation method and its application to the Mediterranean basin-scale circulation. In: Pinardi, N., Woods, J.D. (Eds.), Ocean Forecasting: Conceptual Basis and Applications. Springer Verlag, pp. 281-306

Dong L., Zhou T, Wu B. 2014. Indian Ocean warming during 1958-2004 simulated by a climate system model and its mechanism. Climate Dyn 42: 203-217, doi:10.1007/s00382-013$1722-\mathrm{z}$

Dong L, Zhou T. 2014. The Indian Ocean sea surface temperature warming simulated by CMIP5 models during the twentieth century: Competing forcing roles of GHGs and anthropogenic aerosols. J. Climate 27:,3348-3362, doi:10.1175/JCLI-D-13-00396.1

Dong, L, Zhou TJ, Dai A, Song F, Wu B, Chen X 2016. The footprint of the inter-decadal Pacific oscillation in Indian Ocean sea surface temperatures. Sci. Rep., 6, 21251

Du Y, Xie S.-P 2008. Role of atmospheric adjustments in the tropical Indian Ocean warming during the 20th century in climate models. Geophys. Res. Lett 35: L08712, doi:10.1029/2008GL033631

Du, Y, Xie S.-P, Hu K, G. Huang 2009. Role of Air-Sea Interaction in the Long Persistence of El Niño-Induced North Indian Ocean Warming. J. Clim 22: 2023-2038.

Ebbesmeyer CC, Cayan DR., McLain DR., Nichols FH, Peterson DH, Redmond KT. 1991. 1976 step in the Pacific climate: Forty environmental changes between 1968-75 and 19741984. Proc. Seventh Annual Pacific Climate Workshop, Asilomar, CA, California Department of Water Resources, Interagency Ecological Studies Program, Rep. 26, 115-126. 
Fedorov AV, Philander SG. 2000. Is El Niño Changing? Science 288:1997-2002.

Hansen J, Sato M.2004.Greenhouse gas growth rates. Proc. Natl. Acad. Sci 101: 16109-16114, doi:10.1073/pnas.0406982101

Han W, Vialard J, McPhaden MJ, Lee T, Masumoto Y, Feng M, and de Ruijter WPM .2014. Indian Ocean Decadal Variability: A Review. Bull. Amer. Meteor. Soc 95: 1679-1703.

Han W, Meehl GA, Hu A .2006. Interpretation of tropical thermocline cooling in the Indian and Pacific oceans during recent decades. Geophys. Res. Lett 33:L23615, doi:10.1029/2006GL027982.

Kalnay E., et al. 1996. The NCEP/NCAR 40-Year Reanalysis Project. Bull. Am. Meteorol. Soc 77: $437-471$.

Klein SA, Soden BJ, Lau NC. 1999. Remote sea surface temperature variations during ENSO: Evidence for a tropical atmospheric bridge. J. Climate 12: 917-932.

Kobayashi S, Ota Y, Harada Y, Ebita A, Moriya M, Onoda H, Onogi K, Kamahori H, Specifications and Basic Characteristics. Journal of Met. Soc. Japan doi:10.2151/jmsj.2015-00.

Krishnamurthy L, Krishnamurthy V. 2014. Influence of PDO on South Asian monsoon and monsoon-ENSO relation, Clim. Dyn 42:2397-2410

Lau, N.-C, Nath MJ 2003. Atmosphere-ocean variations in the Indo-Pacific sector during ENSO episodes. J. Clim 16: 3-20.

Lee T, McPhaden MJ. 2010. Increasing intensity of El Niño in the central-equatorial Pacific,

Levitus et al. 2000. Warming of the world oceans. Science 287: 2225-2229.

442

Levitus, Antonov SJ, Boyer T. 2005. Warming of the world ocean, 1955-2003. Geophys. Res. Lett 32: L02604, doi:10.1029/2004GL021592

Madec, G., Delecluse, P., Imbard, I., Levy, C., 1999. OPA 8.1 Ocean General Circulation Model Reference Manual. Note du Pôledemodélisation. Inst. Pierre-Simon Laplace (IPSL), France, No. 11, 91 pp.

Masina S, Di Pietro P, Storto A, Navarra A. 2011. Global Ocean re-analyses for climate applications. Dyn. Atmos. Oceans 52 : 341-366:, doi:10.1016/j.dynatmoce.2011.03.006

Mayer M., K. E. Trenberth, L. Haimberger, and J. T. Fasullo, 2013. The response of tropical atmospheric energy budgets to ENSO. J. Climate 26: 4710-4724, doi:10.1175/JCLI-D-1200681.1

Mayer, M., Haimberger L, Balmaseda M. A. 2014. On the Energy Exchange between Tropical Ocean Basins Related to ENSO. J. Climate 27: 6393-6403 
Pan YH, Oort AH .1983. Global climate variations connected with sea surface temperature anomalies in the eastern equatorial Pacific Ocean for the 1958-1973 period. Mon. Weather Rev 111: $1244-1258$.

Poli et al. 2013. The data assimilation system and initial performance evaluation of the ECMWF pilot reanalysis of the 20th-century assimilating surface observations only (ERA-20C), ERA Report Series 14, [http://www.ecmwf.int/en/elibrary/11699-data-assimilation-system-andinitial-performance- evaluation-ecmwf]

Priya P, Mujumdar M, Sabin, TP, Terray, P., Krishnan R. 2015. Impacts of Indo-Pacific sea surface temperature anomalies on the summer monsoon circulation and heavy precipitation over northwest India-Pakistan region during 2010. J. Climate, 28 (9), 3714-3730

Rao SA, Dhakate AR, Saha SK, Mahapatra S, Chaudhari HS, Pokhrel S, Sahu SK. 2012. Why is Indian Ocean warming consistently? Climatic Change 110: 709-719, DOI 10.1007/s10584-0110121-x

Ratna SB, Cherchi A, Joseph PV, Behera S, Abish B, Masina S. 2016. Moisture variability over the Indo-Pacific region and its influence on the Indian summer monsoon rainfall. Climate Dynamics, 46: 949-965 DOI :10.1007/s00382-015-2624-z.

Rayner et al. 2003. Global analyses of sea surface temperature, sea ice, and night marine air temperature since the late nineteenth century. J. Geophys. Res 108: 4407, doi:10.1029/2002JD002670, D14.

Roeckner E, Bengtsson L, Feichter J, Lelieveld J, Rodhe H. 1999. Transient Climate Change Simulations with a Coupled Atmosphere-Ocean GCM Including the Tropospheric Sulfur Cycle. J. Climate 12, 3004-3032.

Roxy MK, Ritika K, Terray P, Murutugudde R, Ashok K, Goswami BN. 2015. Drying of Indian subcontinent by rapid Indian Ocean warming and a weakening land-sea thermal gradient. Nature Communications, 6:7423

Roxy M, Ritika K, Terray P, Masson S. 2014. The curious case of Indian Ocean warming. $J$. Climate 27: 8501-8509. doi:10.1175/JCLI-D-14-00471.1.

Saji NH, Goswami BN, Vinayachandran PN, Yamagata T. (1999). A dipole mode in the tropical Indian Ocean. Nature 401: 360-363.

Schott FA, Xie S.-P, McCreary Jr. JP. 2009. Indian Ocean circulation and climate variability, Rev. Geophys 47: RG1002, doi:10.1029/2007RG000245

Smith TM, Richard W. Reynolds, Thomas C. Peterson, and Jay Lawrimore, 2008. Improvements to NOAA's Historical Merged Land-Ocean Surface Temperature Analysis (1880-2006). J. Climate 21: 2283-2296.

Tanaka HL, Ishizaki N, Kitoh A. 2004. Trend and interannual variability of Walker, monsoon and Hadley circulations defined by velocity potential in the upper troposphere. Tellus 56A: 250269.

Terray P. 1994. An evaluation of climatological data in the Indian Ocean area. J. Meteor. Soc. Japan,72:,359-386 


\section{3}

Terray P, Dominiak S. 2005. Indian Ocean sea surface temperature and El Niño-Southern Oscillation: A new perspective, J. Clim 18: 1351-1368.

Tokinaga H.,Shang-Ping Xie, Axel Timmermann, Shayne McGregor, Tomomichi Ogata, Hisayuki Kubota, and Yuko M. Okumura, 2012. Regional Patterns of Tropical Indo-Pacific Climate Change: Evidence of the Walker Circulation Weakening. J. Climate 25: 1689-1710.

Trenberth, K. E. 1997. The Definition of El Niño. Bulletin of the American Meteorological Society 78: 2771-2777

Trenberth KE, Caron JM, Stepaniak DP,Worley S. 2002.Evolution of El Niño-Southern Oscillation and global atmospheric surface temperatures. J. Geophys. Res 107(D8), doi:10.1029/2000JD000298.

Trenberth KE, Fasullo JT, Kiehl J. 2009. Earth's global energy budget. Bull. Amer. Meteor. Soc 90: $311-323$.

Tyrrell T. 2011 Anthropogenic modification of the oceans. Phil. Trans. R. Soc. A 369: 887- 908, doi:10.1098/rsta.2010.0334

Vecchi, GA.,Soden BJ, Wittenberg AT, Held IM, Leetmaa A, Harrison MJ. 2006. Weakening of tropical Pacific atmospheric circulation due to anthropogenic forcing. Nature 441: 73-76

Wang B. 1995. Interdecadal changes in El Niño onset in the last four decades. J. Climate 8: $267-285$

Wang B, An S.-I. 2001. Why the properties of El Niño changed during the late 1970s. Geophys. Res. Lett 28:3709-3712.

Williams AP, Funk CA. 2011. Westward extension of the warm pool leads to a westward extension of the Walker circulation, drying eastern Africa. Clim. Dyn. 37: 2417-2435

Yeh S-W, Kirtman BP, Kug J-S, Park W, Latif M. 2011. Natural variability of the central Pacific El Niño event on multi-centennial timescales, Geophys.Res. Lett., 38, L02704

Yamagata T, Behera SK, Luo J.-J, Masson S., Jury MR, Rao SA.2004. Coupled OceanAtmosphere Variability in the Tropical Indian Ocean, in Earth's Climate (eds C. Wang, S.P. Xie and J.A. Carton), American Geophysical Union, Washington, D. C.. doi: 10.1029/147GM12

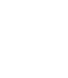

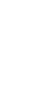

2


527 Table

528 Table 1. List of years considered to compute the composite anomalies

\begin{tabular}{|c|c|c|}
\hline & El Niño & La Niña \\
\hline \multirow{10}{*}{$\begin{array}{l}0 \\
\frac{0}{2} \\
1 \\
0 \\
0\end{array}$} & 1951 & 1950 \\
\hline & 1953 & 1954 \\
\hline & 1957 & 1955 \\
\hline & 1958 & 1956 \\
\hline & 1963 & 1964 \\
\hline & 1965 & 1970 \\
\hline & 1968 & 1971 \\
\hline & 1972 & 1973 \\
\hline & -- & 1974 \\
\hline & -- & 1975 \\
\hline \multirow{9}{*}{ 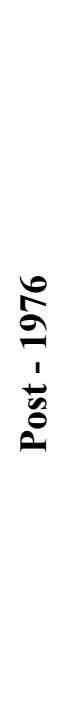 } & 1982 & 1988 \\
\hline & 1986 & 1998 \\
\hline & 1987 & 1999 \\
\hline & 1991 & 2000 \\
\hline & 1992 & 2010 \\
\hline & 1997 & --- \\
\hline & 2002 & --- \\
\hline & 2004 & --- \\
\hline & 2009 & -- \\
\hline
\end{tabular}




\section{Figures}

(a) Anomaly for Base Year (1961-1990)
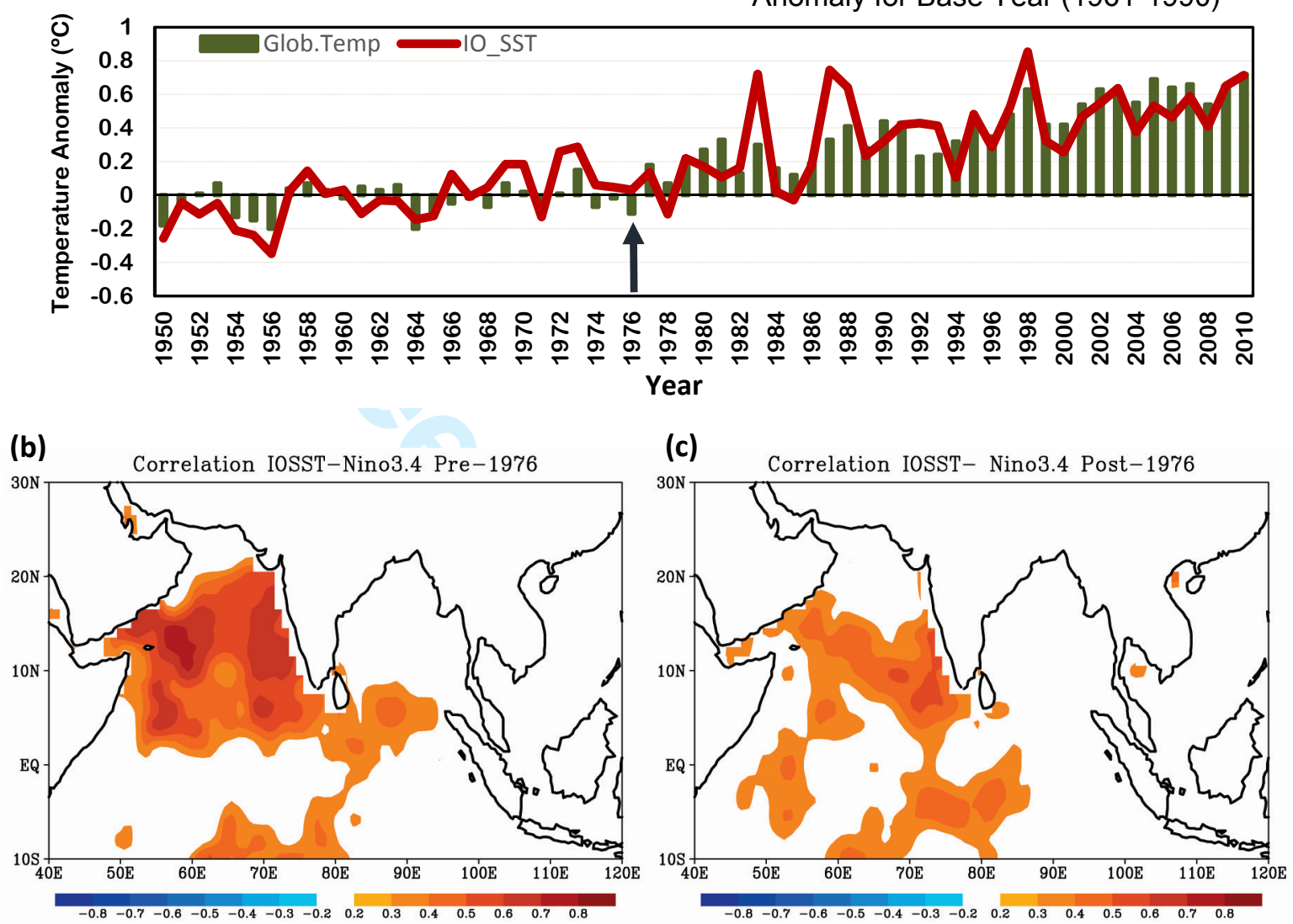

Fig1 (a) Time series of global surface temperature and IO SST anomaly. Base year of 1961-1990 is considered. The arrow indicate the year 1976 from which the global temperatures shows a monotonous increase. SST anomaly is taken for the IO region $\left(40^{\circ} \mathrm{E}-110^{\circ} \mathrm{E} ; 10^{\circ} \mathrm{S}-25^{\circ} \mathrm{N}\right)$. Correlation between detrended IO-SST and Niño 3.4 during JJAS of (b) Pre-1976 (c) Post-1976. Only values significant at $95 \%$ level are shown. 

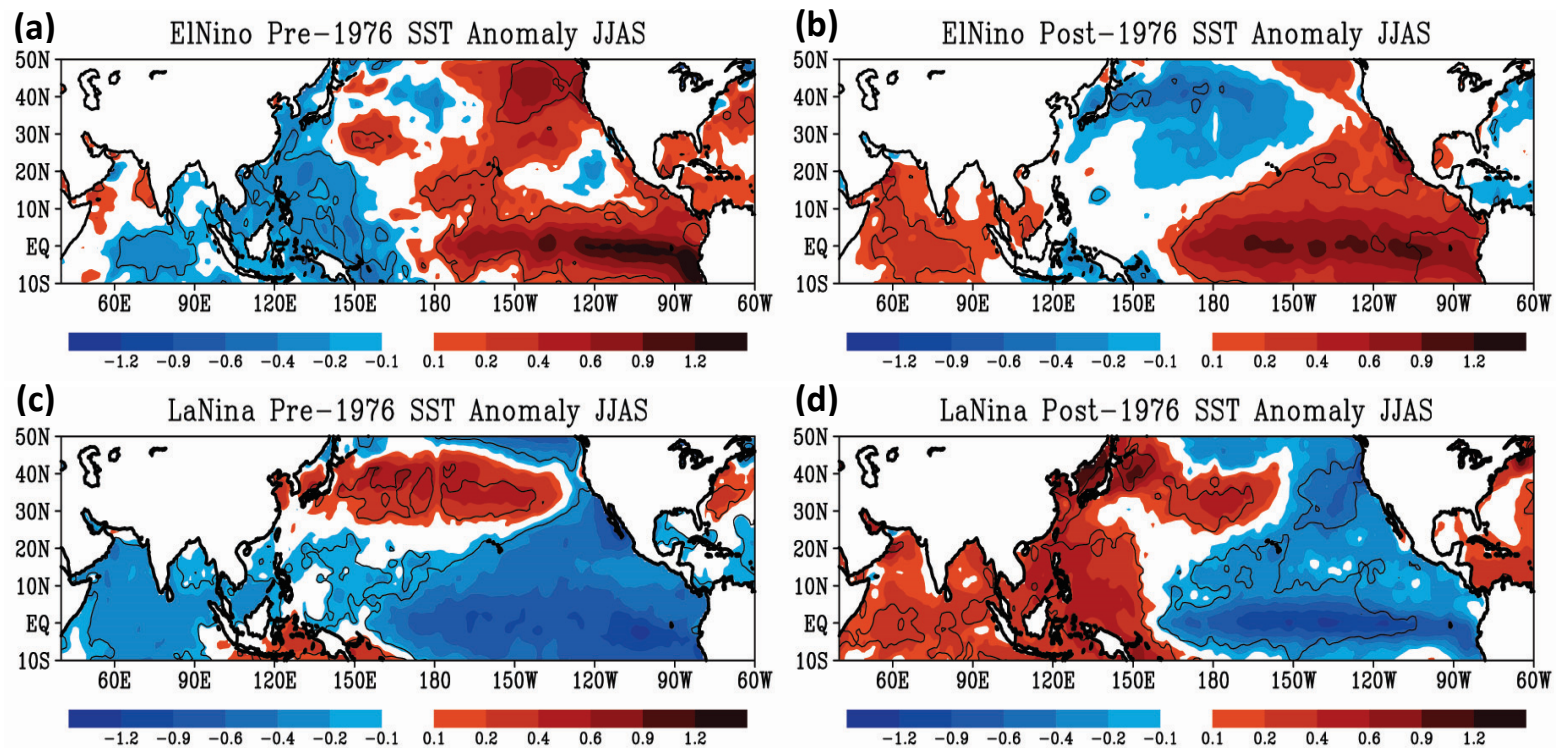

(e)

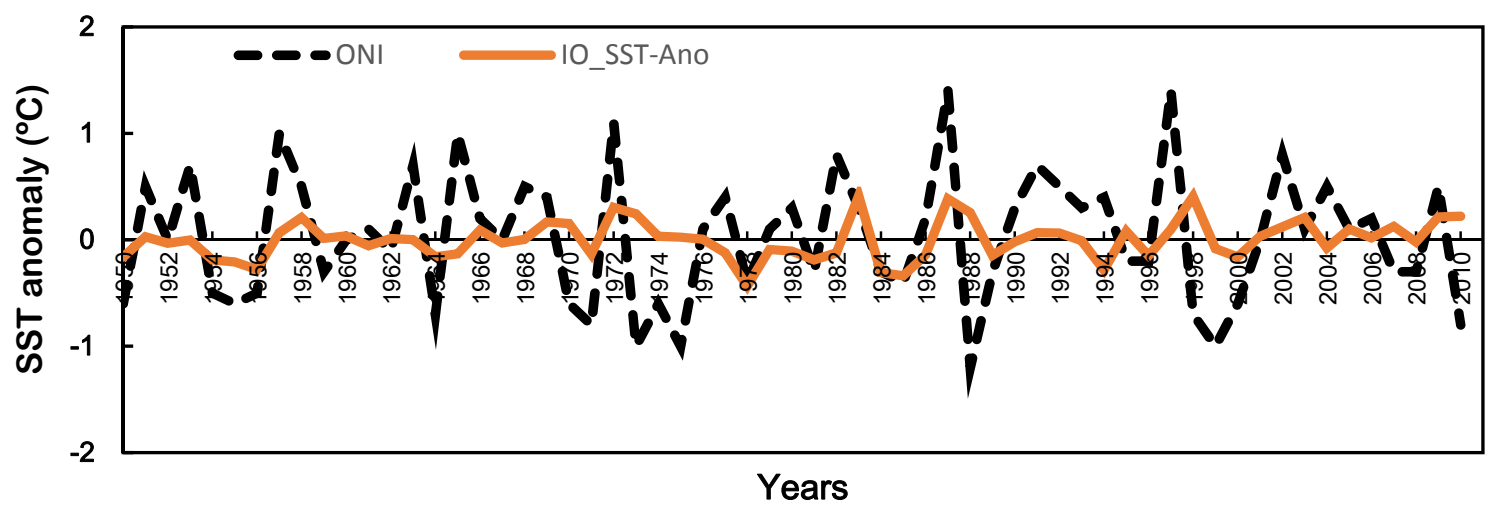

Fig 2. Composite anomalies of detrended SST $\left({ }^{\circ} \mathrm{C}\right)$ of $(\mathrm{a}, \mathrm{b})$ El Niño and $(\mathrm{c}, \mathrm{d})$ La Niña events in the periods pre and post 1976, respectively. The events used to build the composites are listed in Table 1. Contours indicate regions significant at 95\% level. (e) Niño 3.4 SST anomalies (dashed line) and IO SST anomalies (solid line). 

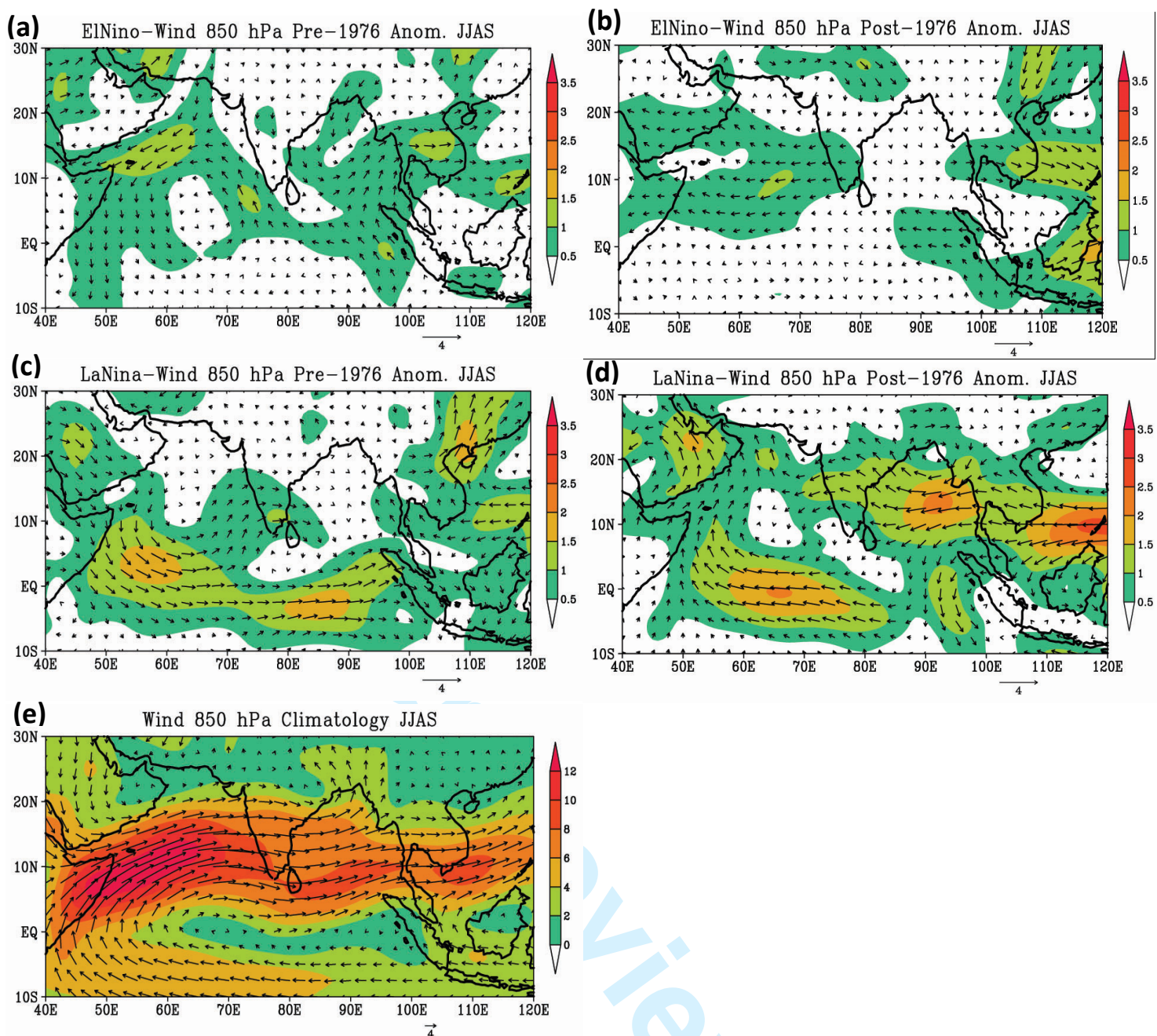

Fig 3 Same as Fig. 2 but for wind anomalies at $850 \mathrm{hPa}\left(\mathrm{ms}^{-1}\right.$; vectors) and associated magnitude (shaded) of (a,b) El Niño and (c,d) La Niña events in the periods pre and post 1976, respectively. (e) JJAS mean climatology of wind at $850 \mathrm{hPa}$. 
(a) ElNino Pre 1976 Walker Anomaly JJAS

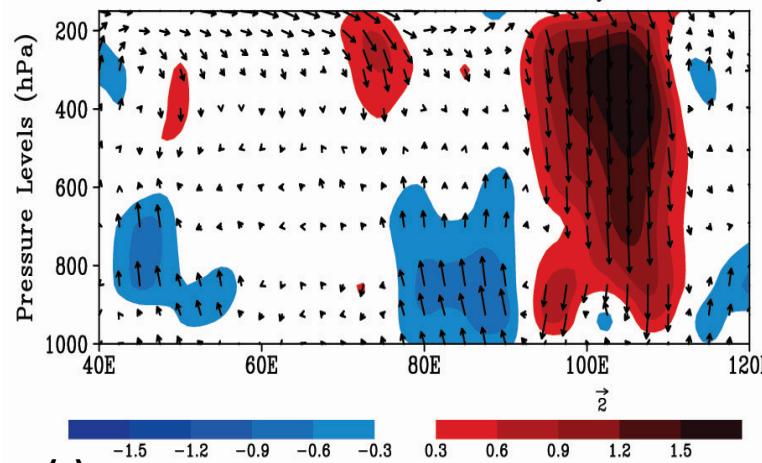

(c) LaNina Pre 1976 Walker Anomaly JJAS

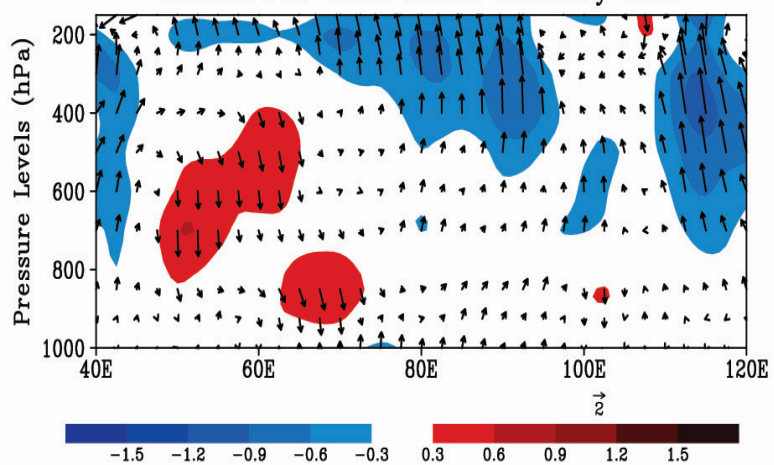

(b) ElNino Post-1976 Walker Anomaly JJAS

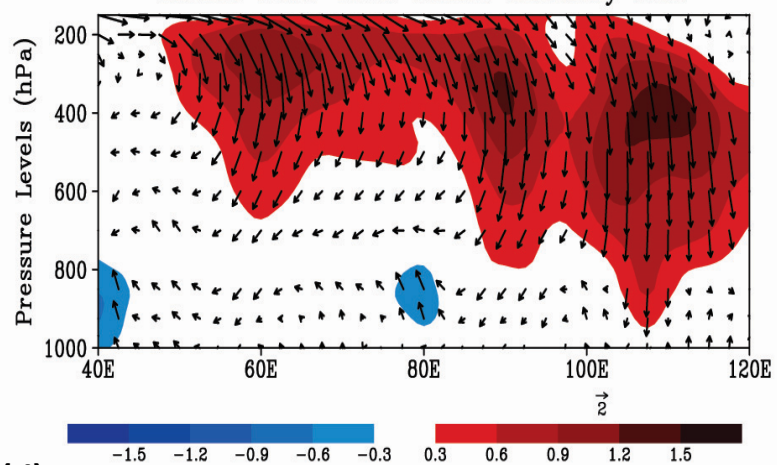

(d)

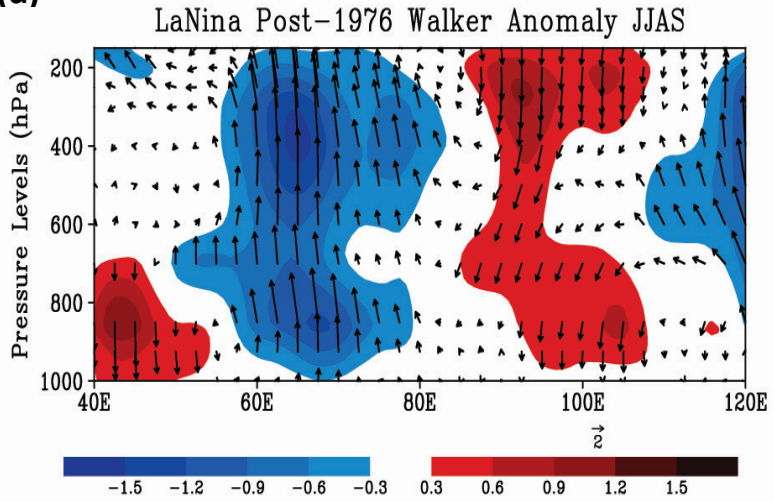

Fig 4 (a,b) El Niño and (c,d) La Niña composite anomalies of the Walker circulation averaged over $5^{\circ} \mathrm{S}-10^{\circ}$ $\mathrm{N}$ during pre and post 1976 events, respectively. The vectors denote the zonal winds in $\mathrm{ms}^{-1}$ and omega in $\mathrm{Pa} \mathrm{s}^{-1}$ (positive downward). 
(a)

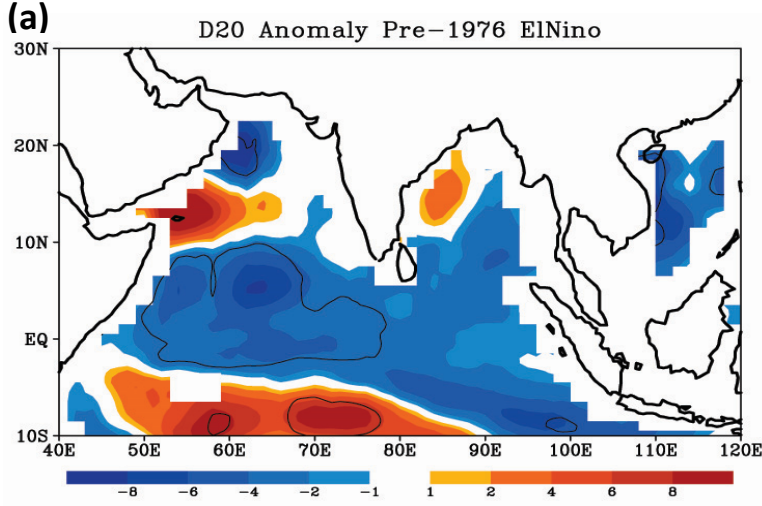

(c)

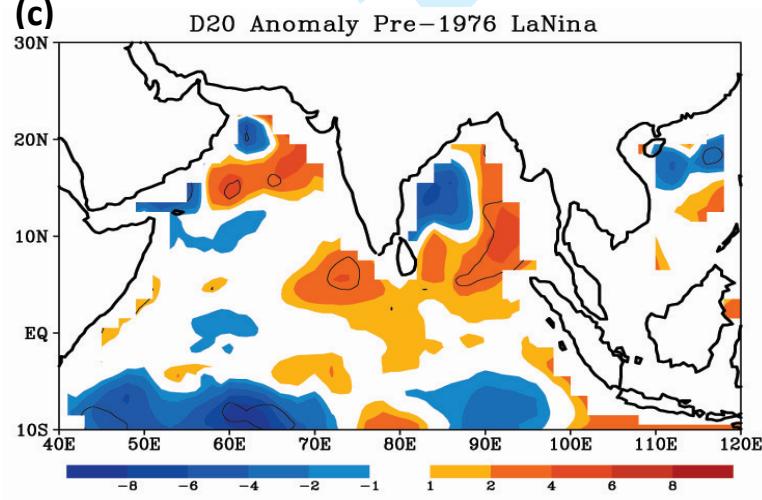

(b)

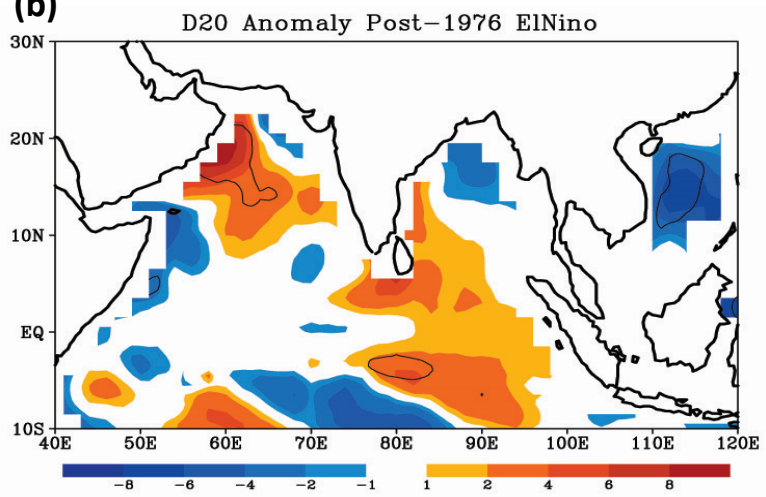

(d)

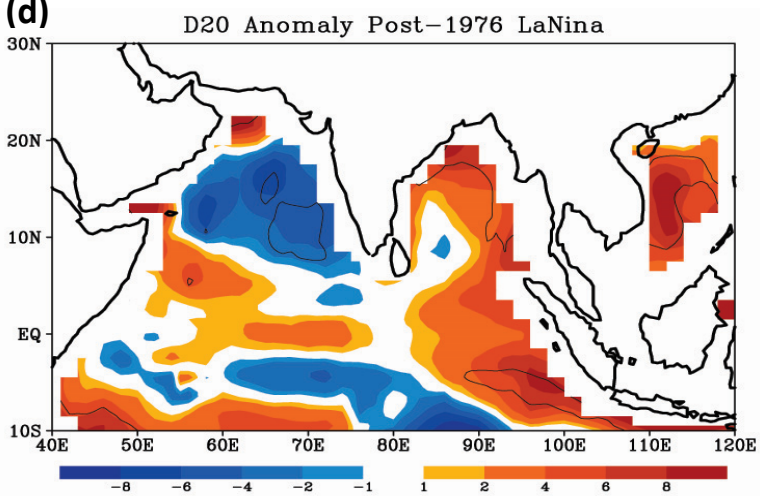

Fig 5. Composite of depth of $20^{\circ} \mathrm{C}$ isotherm anomalies (m) used as a proxy for the thermocline depth of (a,b) El Niño and (c,d) La Niña events in the periods pre and post 1976, respectively. Contours indicate regions significant at 95\% level 
(a) Temperature Profile Anomaly Pre-1976 ElNino

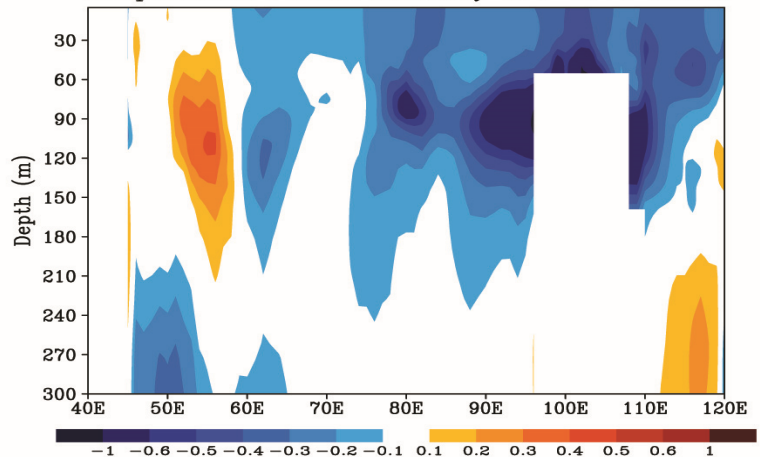

(b) Temperature Profile Anomaly Post-1976 EiNino

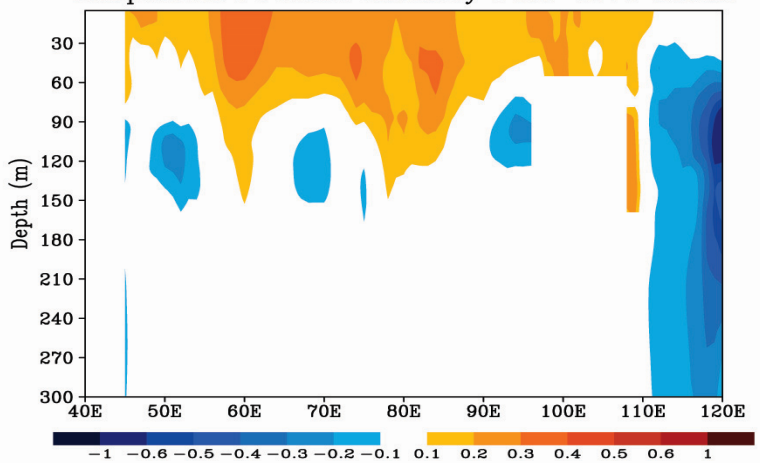

(c)

(d)
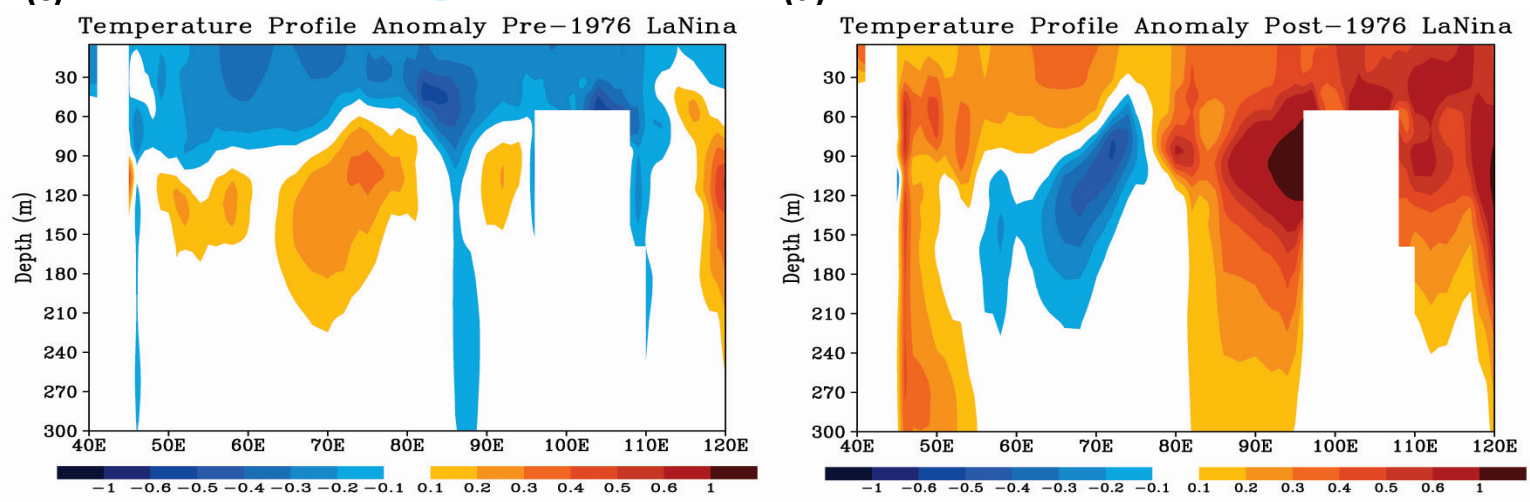

Fig 6. (a,b) El Niño and (c,d) La Niña composite anomalies of temperature $\left({ }^{\circ} \mathrm{K}\right)$ profiles in the first $300 \mathrm{~m}$ averaged in $0-20^{\circ} \mathrm{N}$ during pre and post 1976 events, respectively. 
(a) Zonal Curr. Anom. Pre-1976 ElNino CIGODAS

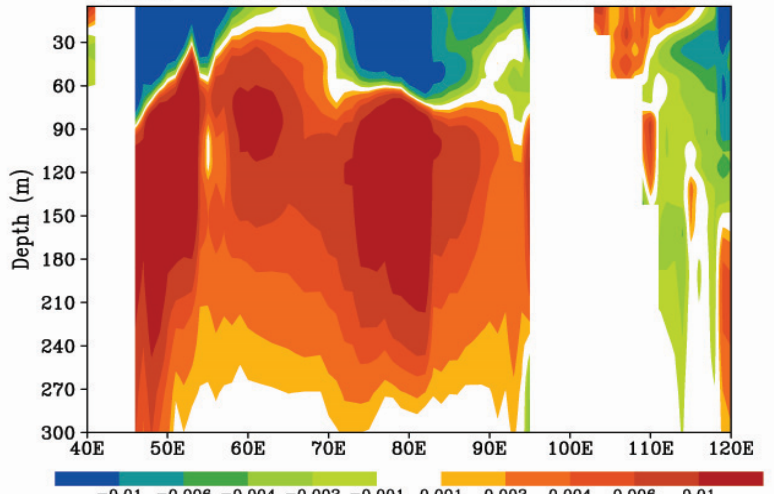

(b) Zonal Curr. Anom. Post-1976 ElNino CIGODAS

(c)

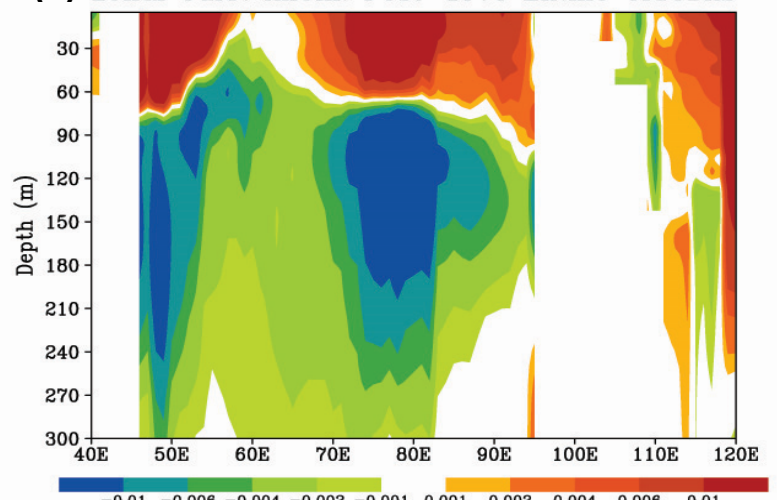

Zonal Curr. Anom. Pre-1976 LaNina CIGODAS

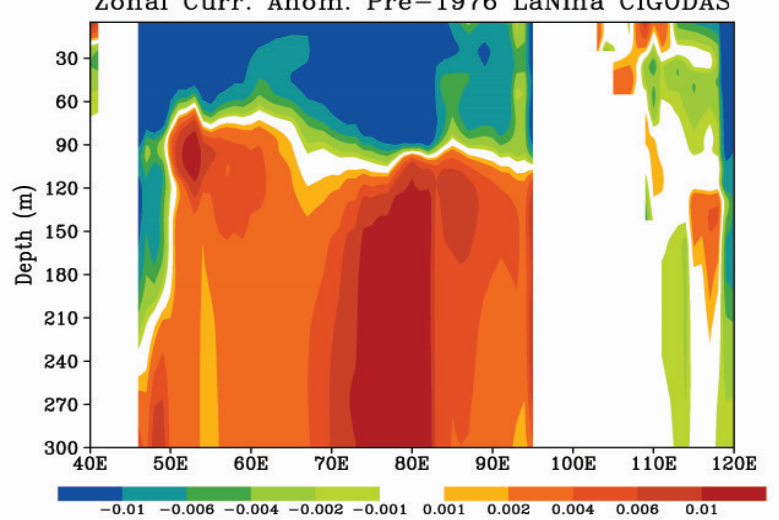

(d)

Zonal Curr. Anom. Post-1976 LaNina CIGODAS
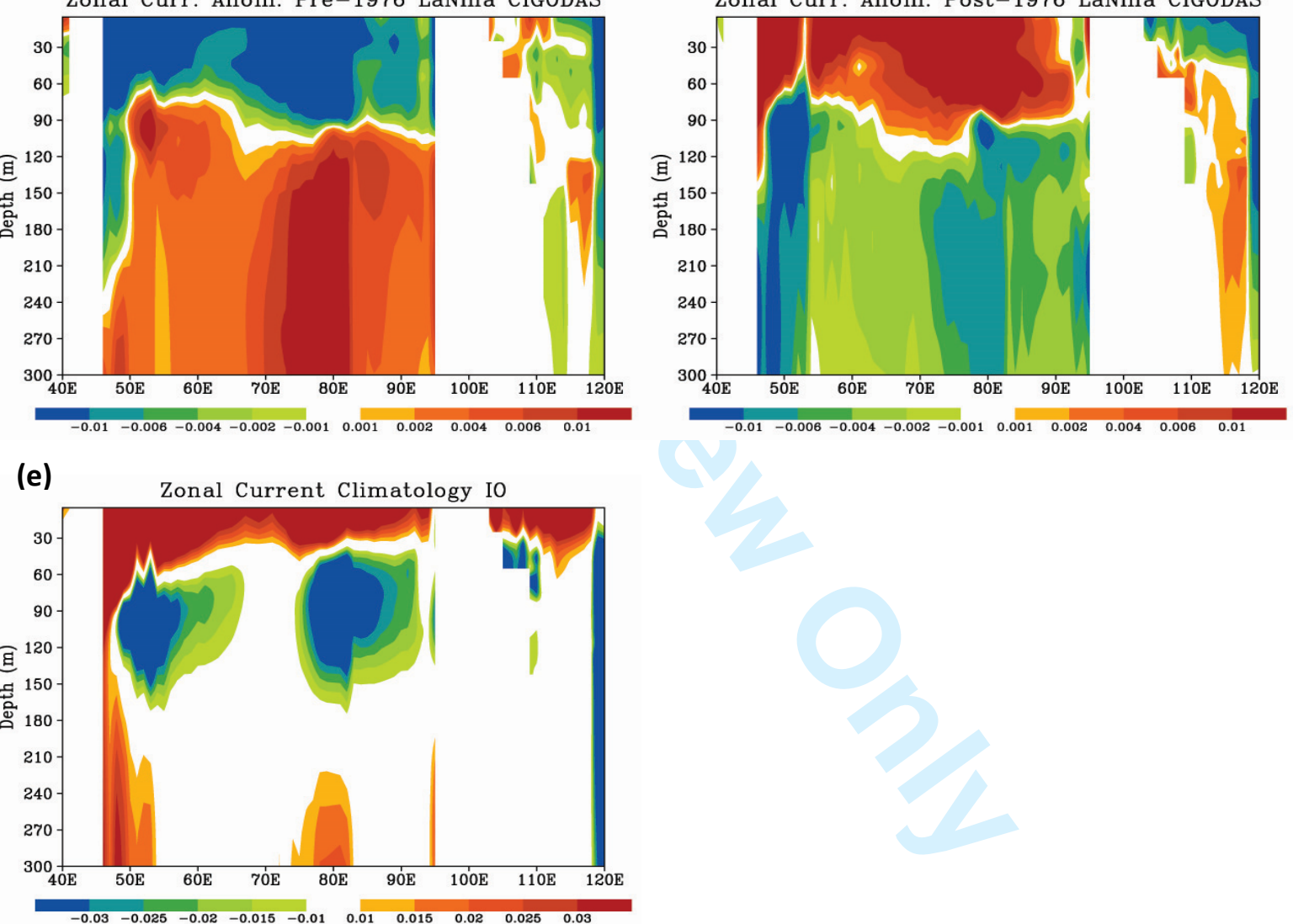

Fig 7. Same as Fig. 6 (a-d) but for zonal currents $\left(\mathrm{ms}^{-1}\right)$ anomalies (e) JJAS mean climatology 
(a)

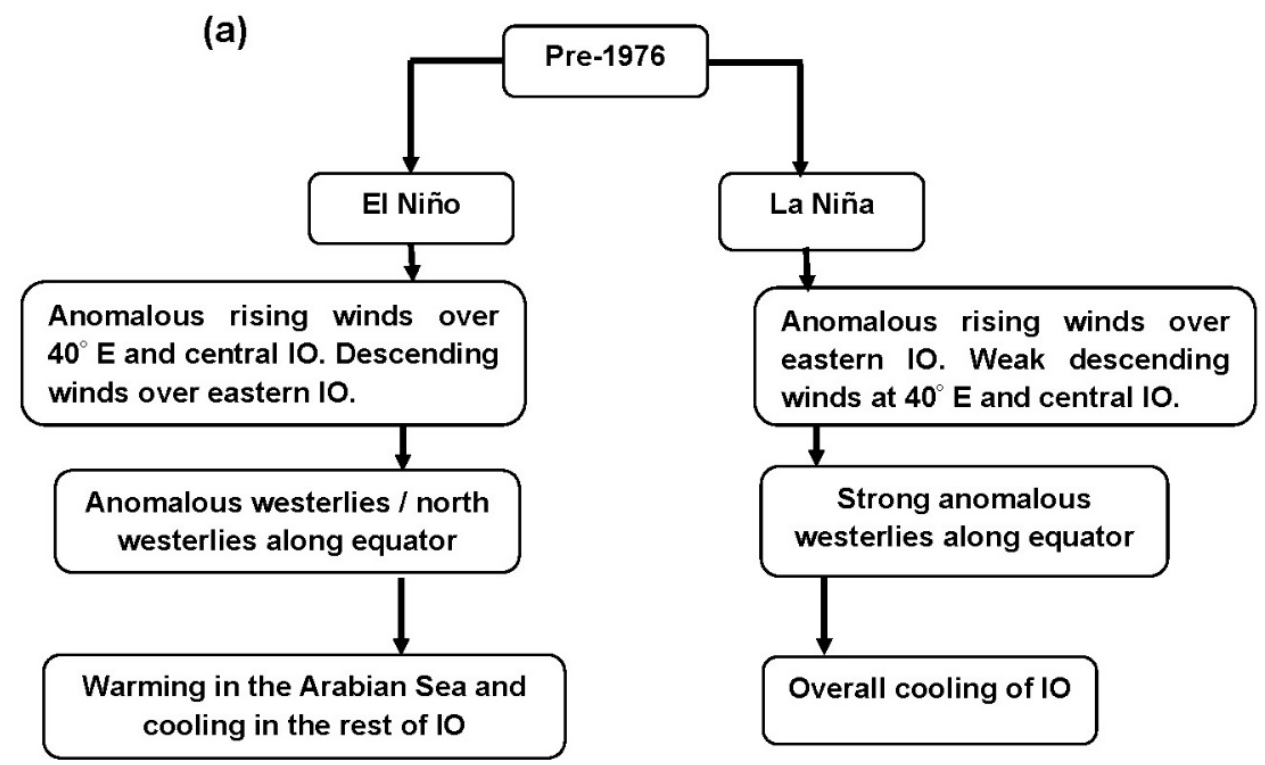

(b)

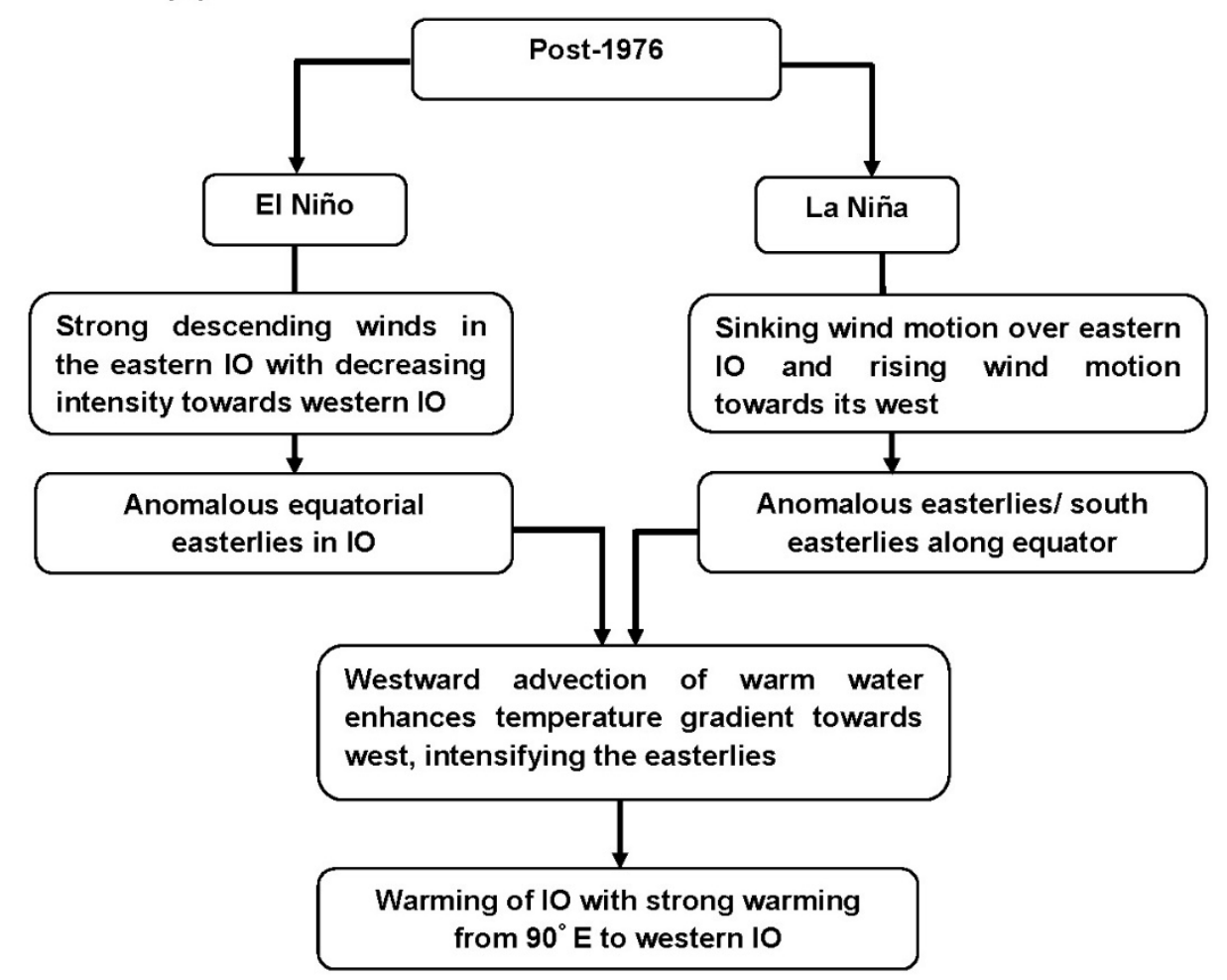

Fig 8. Schematic diagram of the IO warming due to changes in the atmospheric circulations during (a) pre-1976 and (b) post-1976 


\section{Supplementary Figures}

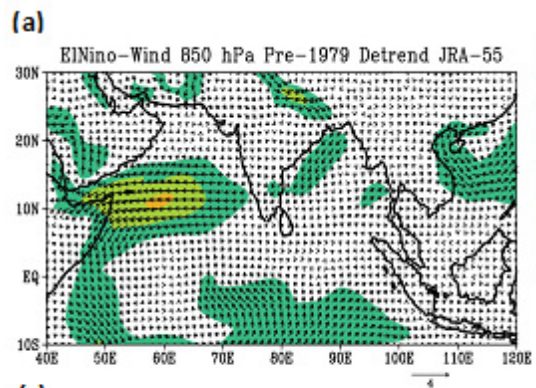

(b)
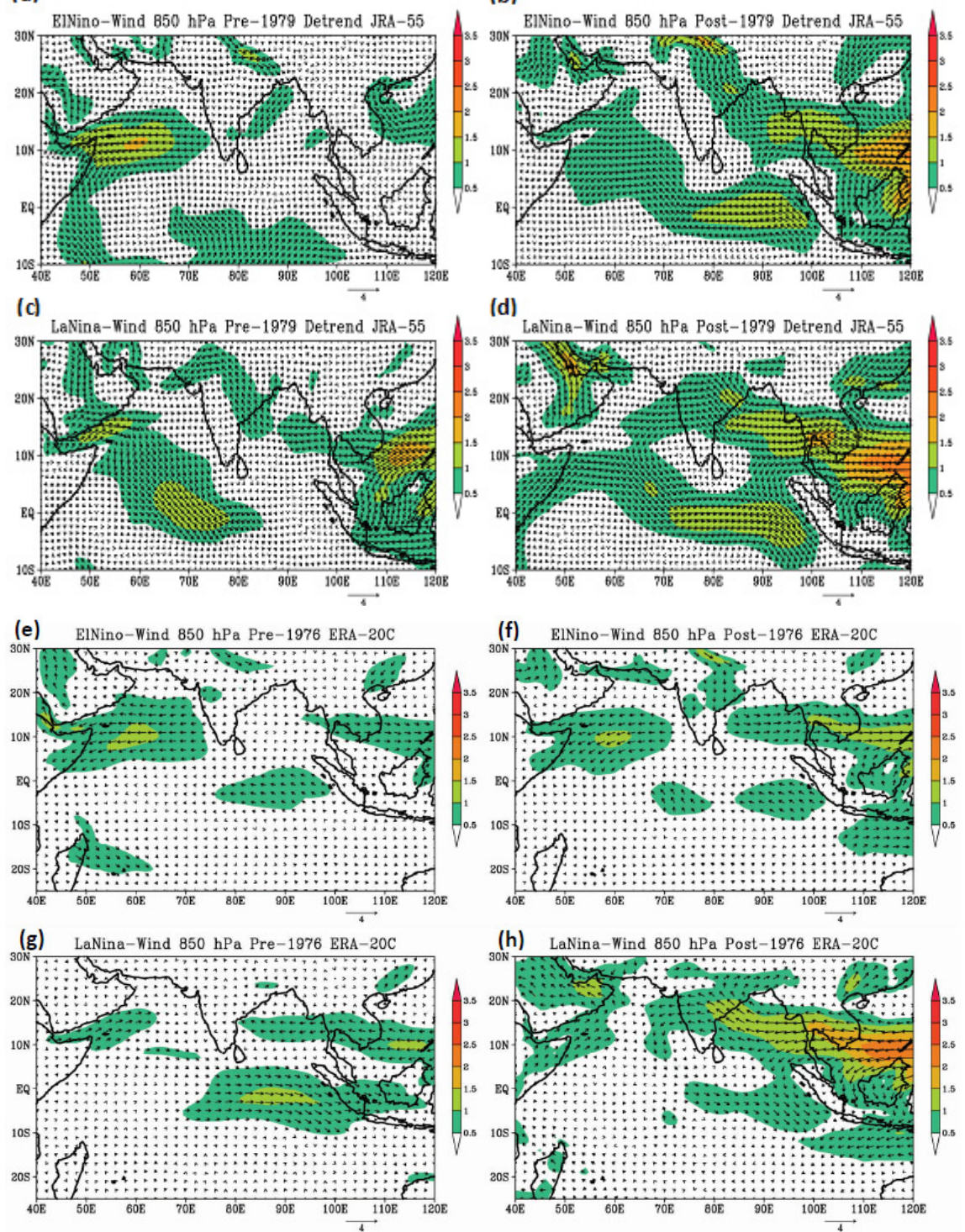

(h) LaNina-Wind $850 \mathrm{hPa}$ Post-1976 ERA-20C
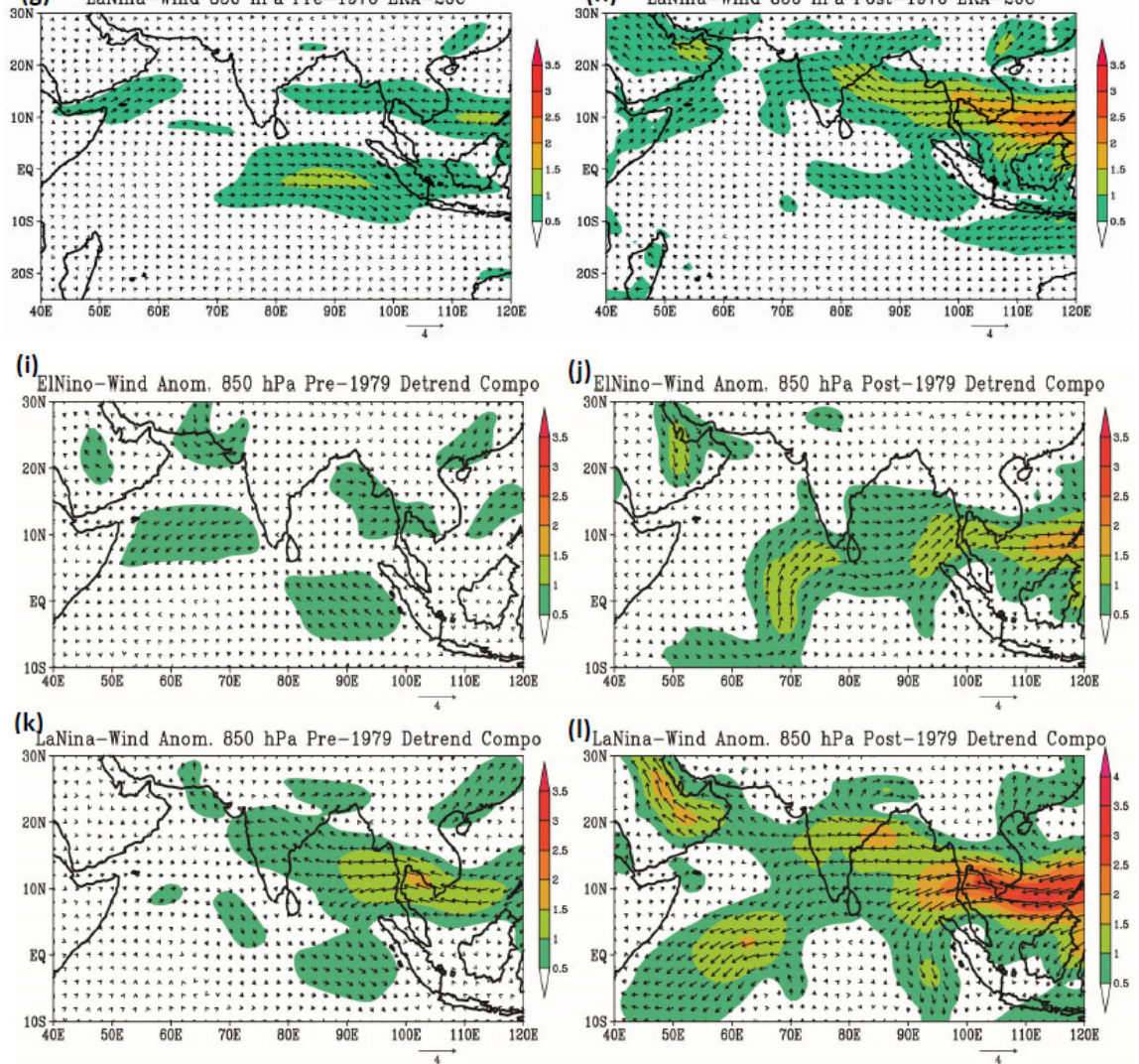

Fig S1. Similar to Fig 3 but using JRA-55 (a-d), ERA-20C (e-h) and 20CRv2 (i-1) re-analyses. 

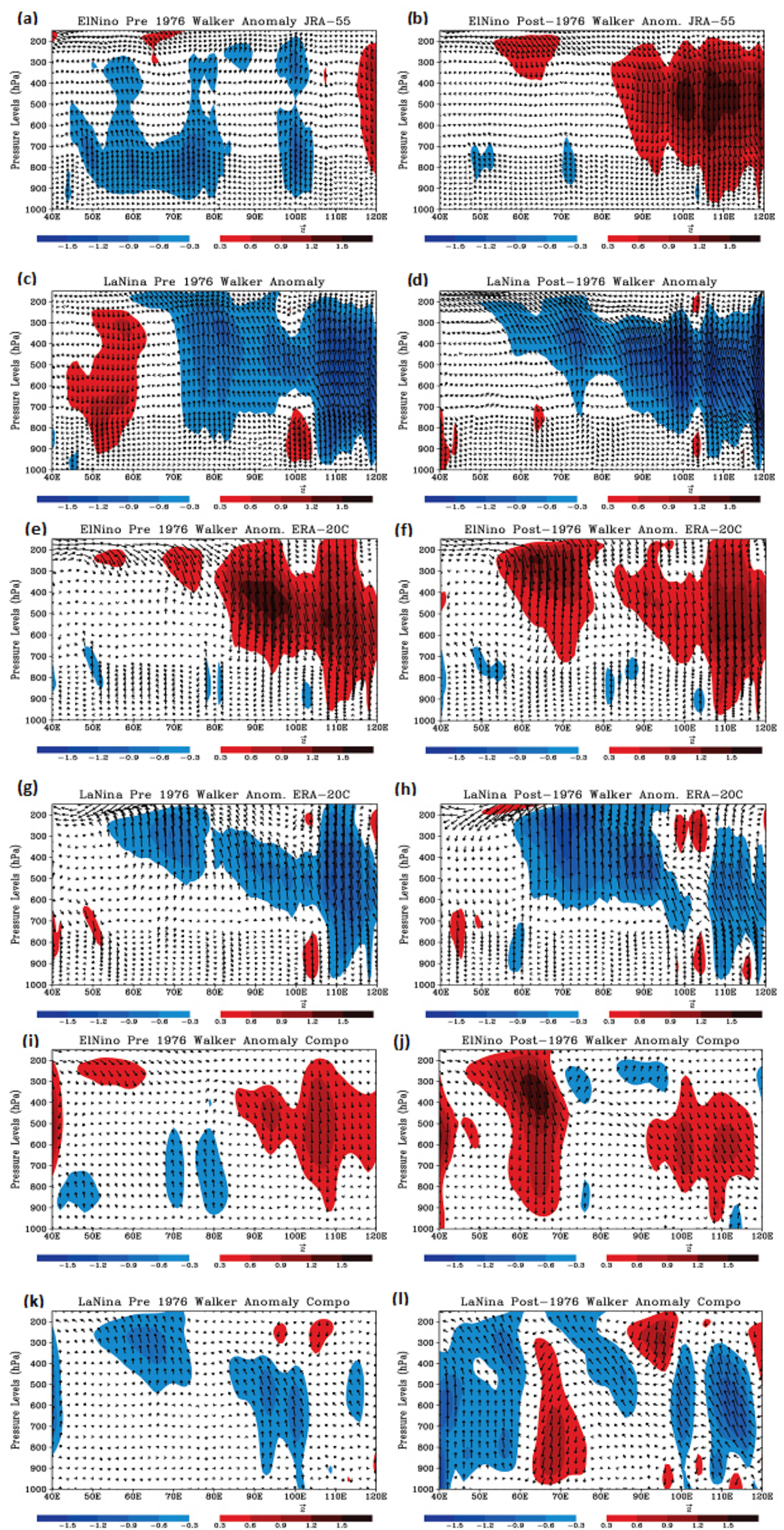

Fig S2. Similar to Fig 4 but using JRA-55 (a-d), ERA-20C (e-h) and 20CRv2 (i-1) re-analyses. 

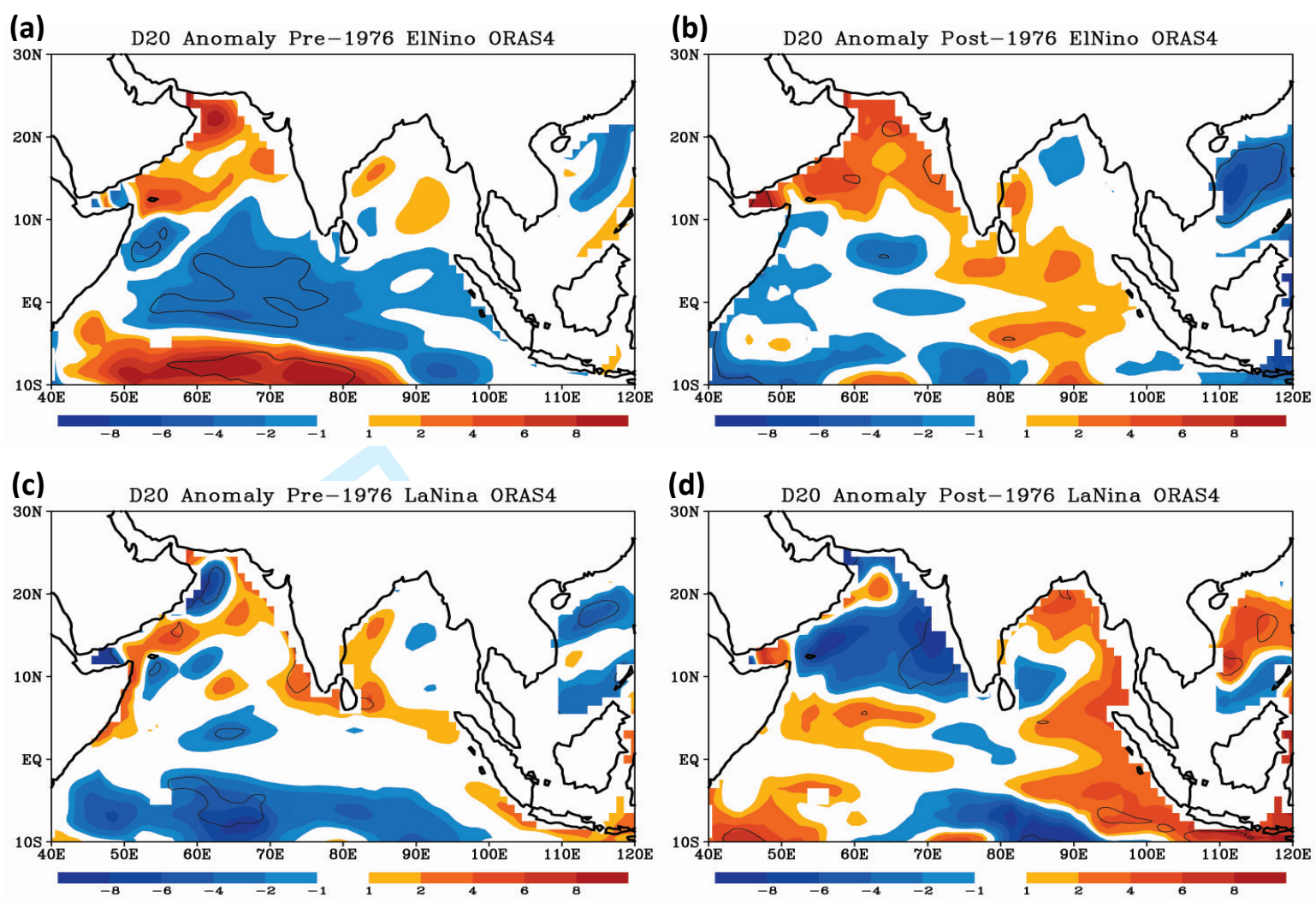

Fig S3. Similar to Fig 5 (a-d) but using ORAS4 re-analysis. 
(a) Temperature Anomaly Pre-1976 EINino ORAS4

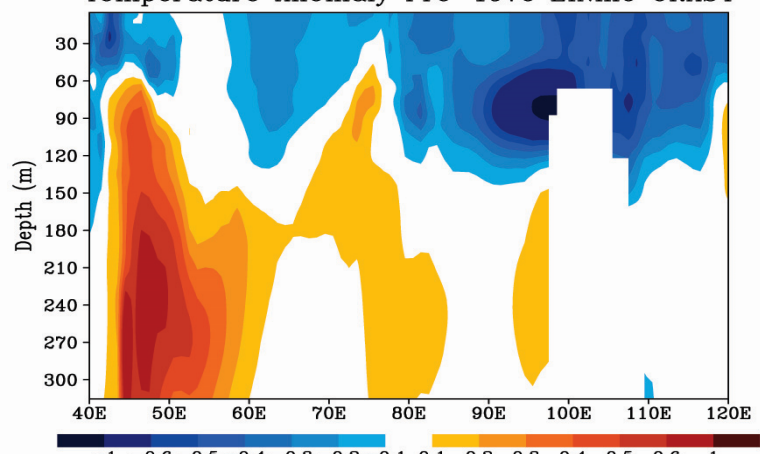

(b) Temperature Anomaly Post-1976 EINino ORAS4

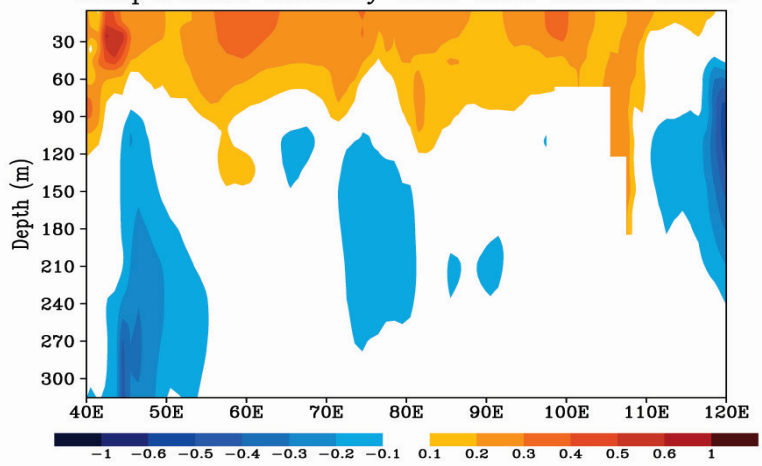

(c)

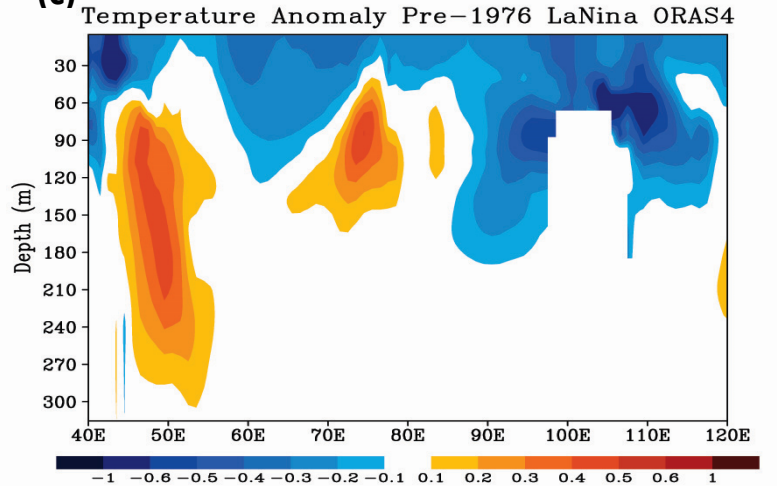

(d)

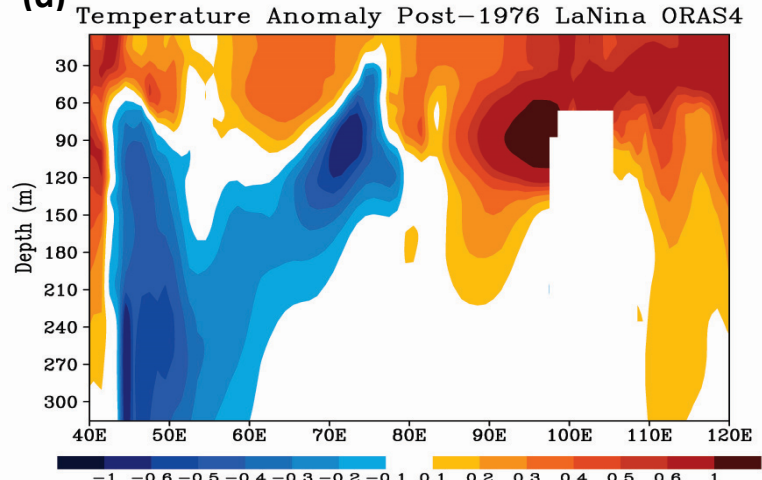

Fig S4. Similar to Fig 6 (a-d) but using ORAS4 re-analysis. 
(a) Zonal Curr. Anom. Pre-1976 ElNino ORAS4

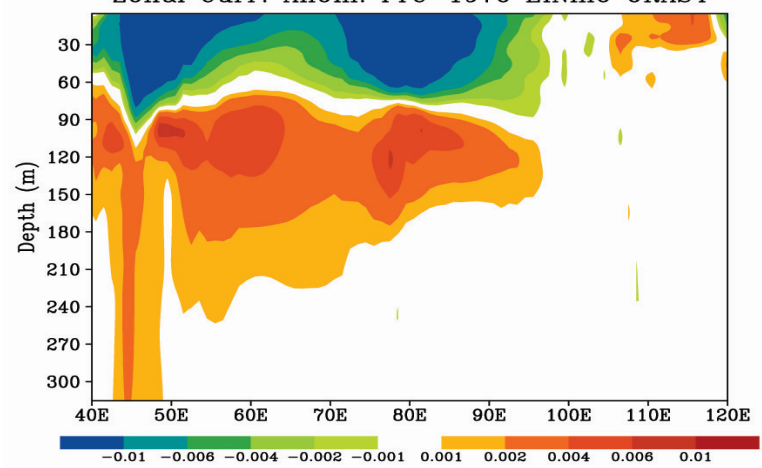

(c) Zonal Curr. Anom. Pre-1976 LaNina ORAS4
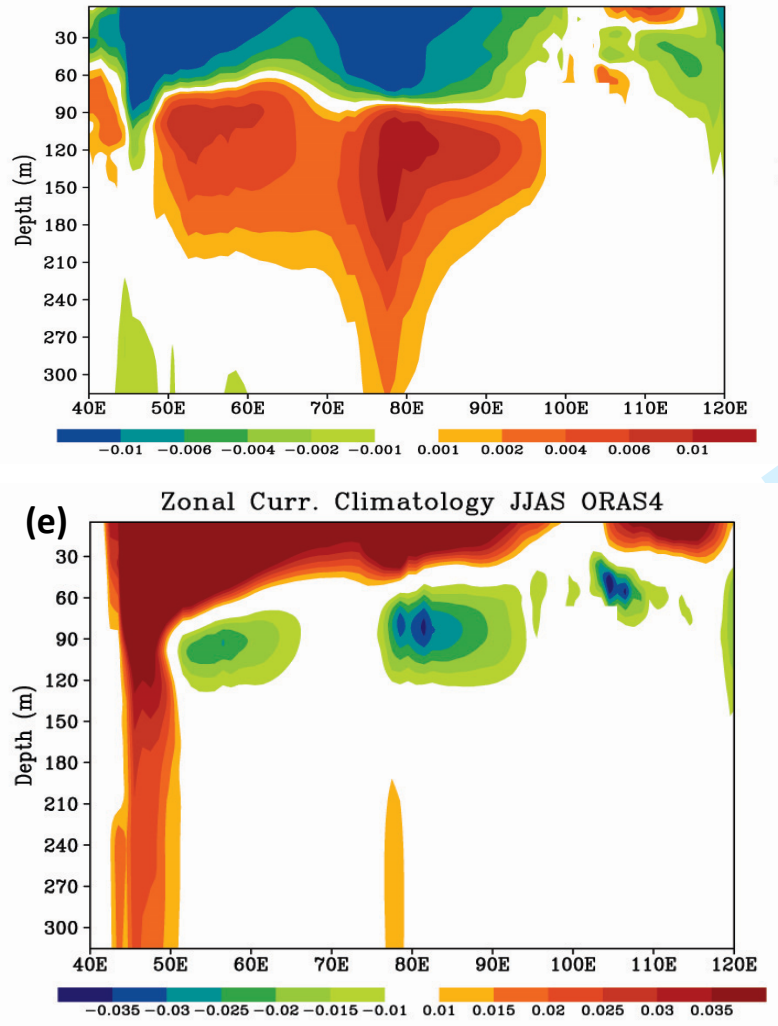

(b) Zonal Curr. Anom. Post-1976 ElNino ORAS4

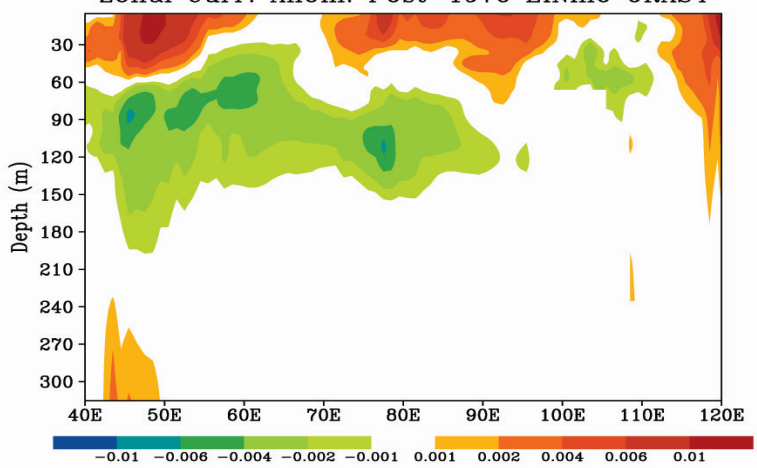

(d) Zonal Curr. Anom. Post-1976 LaNina ORAS4

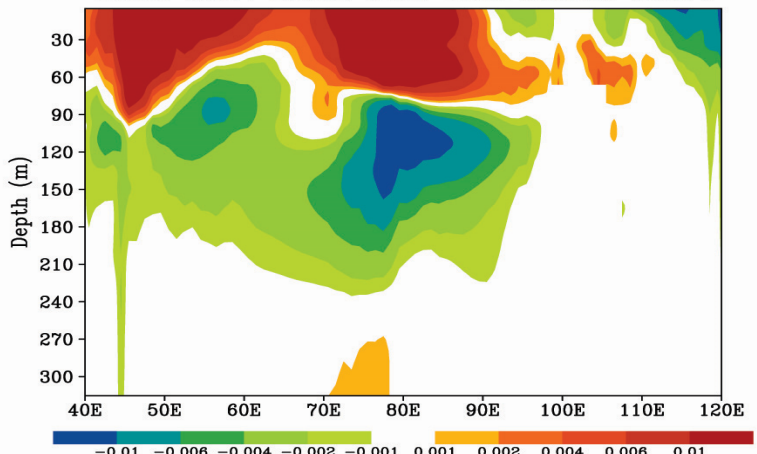

Fig S5. Similar to Fig 7 (a-e) but using ORAS4 re-analysis. 